\title{
胎児皮膚の分裂線と毛流との関係に就て
}

\author{
九州畕科大学第一解剖学教室 (主任 中山種秋教授)
}

阿部董

（本論文の要旨は昭和 33 年 7 月 4 日、日本解剖学会第63回総会の席上でしれ学表した）

目次

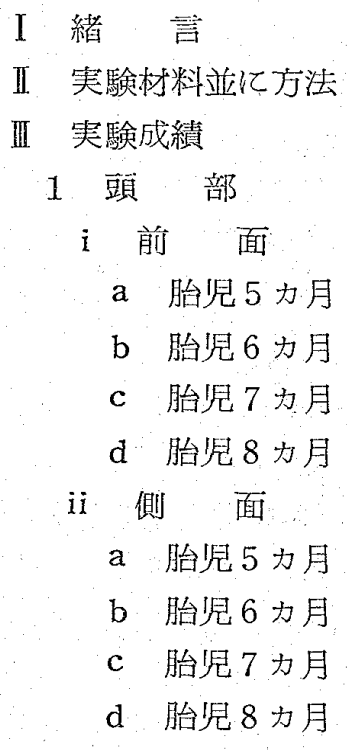
a 胎児 5 力月
b 胎児 6 力月
c 胎少 7 力月
d 胎览 8 力月

iii 上面
a 胎完 5 力月
b 胎览 6 力月
c 胎巟 7 力月
d 胎児 8 力月

iv 後 面
a 胎少 5 力月
b 胎览 6 力月
c 胎児 7 力月
d 胎览 8 力月

2 小 括

3 背 部

a 胎览 6 力月

$\mathrm{b}$ 胎览 7 力月

c 胎览 8 力月

d. 胎児 9 力月 $\mathrm{e}$ 胎児10力月

4 小括

5 組織学的所見

IV 総括立后に考按

$V$ 結 諭

文献

I 緒䓂

分裂線に関する研究は 1836年 Duputren が初めて 皮慮の价裂線について報告した後に 1859年 Malgarice、1861年 Langer がそれぞれ皮首の分裂線を研 究した。その後幾多の業績が先人によつてなされてい るが、わが教室においても各種動物の比較解剖学的研 究並に発育に伴う変化を検索しつつありその結果、 骨分裂線の線系はその外形に支配され又発育方向の 示現であり、不整裂線は所謂防彗反応として骨質の示 す直接的な機能表現であるとの見解学持つに至つた。 又軟部組織については従来、小木層 (1942)、友田 (1949)、山本（1950）、連理（1951〜52）、西尾（1951）、 橋本（1954）の報告があり、わが教室においても土佐 が哺乳動物眼球瑟膜の分裂線江関する比輘解剖学的研 究を行い、鶴丸は犬の睪丸固有䩞膜及び卵栄について その発育に伴う変化を検索中であり骨分裂線の場合之 同様の所見を得つつある状況である。

私は胎児皮膚の分裂線と毛流との関係について特に その発育に伴う変化を実験観察したが、睆述の如く分 裂線はその外形に支配されるのであるが、毛流と分裂 線を比較観察するととは外形をさらに細かい観点に立

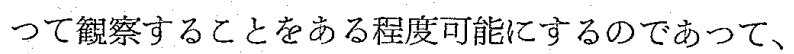
このととは従来なされたわが教室に打竹る研究成果を さらに発展し得るものと推定して本実験を行つた。

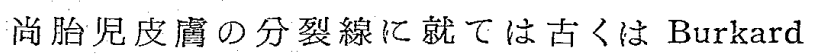


（1903）の業續があり、邦人胎児では福井（昭11）の 研究がある。文胎罗の毛流に就ては山浦（炤5）の 研觉がある。山浦牥日本人胎児毛線の形態特々その個 人的相違に就て 検索し、その中で毛線の形斏は性及 び胎児月令に関係しないと、全身毛流像の一致する 者のないとと、日本人日人間に毛流の形態に相違のな いととを報告し、その他新態的に詳細子研究を行って わる。一方福井は 3 力月から10力月宗での胎罢の皮膚 分裂線について記載し、分裂線系はその機能適応し た棈築的唋張線であると推定し、その緊張力線は生長 と其商化するものであるとしているが、発育方向の 示現であると絓論はしていない。不不整裂線について はその存在は記述しているが、その意味については全 く言及していない。ただてカ月胎罗の頭損部に瀜紋状

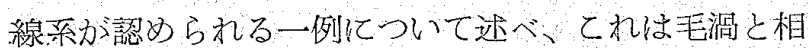
似しているに非ずやとしているか，それ以上深く追求 はしていない。しのように邦人胎児の分裂線と毛流て ついての個々の研究はあるが相互の関係についての系 統的な研究はその例を見ない処であって私は本实駼て よつて聊か興味ある知囬を得るしとが出来たので、て 乙に報告し諸賢の御批判を仰ぐ次第でする。

\section{II 実験材料並に方法}

毛流は胎先 5 力月加方先づ頭部に発生し次で 6 力月 そ至り背部及び胸腹部毛流が出現する。背部及び脑腹 部毛流の中では北部毛流が観察に便であり父頭部毛流 で特嘪の所見を呈するものに毛渦があるが、背部にも

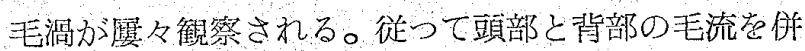
せて観察し以て分裂線との相関扈迫求するてとが有意 義であると思惟し、本実験では頭部及び背部の毛流と 分裂線克観察した。

頭部毛流は 5 力月汃ら 8 カ月までの間方䔘察に最も

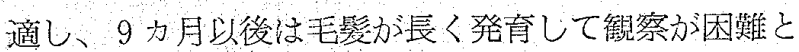
なる。北部毛流は 6 力月から10力月灾で観察が可能で ある。徒つて頭部は 5 力月加ら 8 力月までの 4 例を、

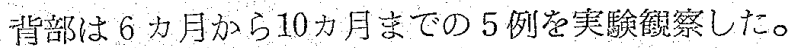
な打胎省は人工流産後直ち汇 5 力月胎览は $10 \%$ フオ ルモール中に保存し、 6 力月胎罗以後は僢静脈汃ら10 \%フォルモールの防有注入起施した後10\%フォルモー ル中に保存したもの使用しだ。該標本の毛流先先づ 肉眼的に観察し必要に応じてルーペを併用しながら正 確に写生した。その後縫針に墨汁总浸けながら皮膚に 䧿直に穿刺を行い余分の墨汁は水洗した。な打 7 カ月

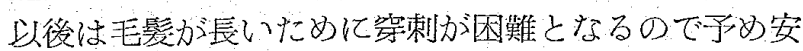

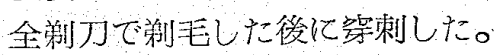

\section{II 实 驗 成 續}

身体部位 (Region) については胎览你末だ発育が 不充分なために备境界の不明膫な場合が多いが、一応 成人のそれそ準じて記載した。但し特別の湯合を除い て眼窝下部、煩骨部、耳下腺昗筋部及び頓部は一括し て煩部と表現するととにした。

$$
\text { I 頭 部 }
$$

a 胎览 5 力月

分裂線は頭頂部左 $1 / 3 よ り$ 左右側頭部门向つて热状を

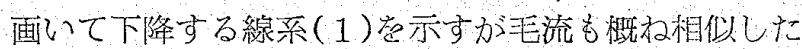
走向 (a) 觉示す。

顔部の分裂線は眼篬部の中上眼臉部では眼裂に向う 斜走線系 $(2)$ をなし、一方毛流毛同じ走向 $(\mathrm{b})$ 孛示す 分、下眼臉部では分裂線は眼裂に平行の横走線系 (3) を示すのに対して毛流は斜走 (c) する。

頓部は分裂線孔外側に向って斜走する(4)が毛流は 5 カ月では未だての部に発生していない。

\section{b . 胎览 6 力月}

分裂線络頭頂部中央より雨側頭部々向う左右の狐快 線系群 (1)を示し、その線系の一部は乱れている。文就 線系群と後述する左右の眼䓨部上牛少ら前磌部下端々 加けて存する係踥状線䍃 (2) との間䎲若干の不整裂線

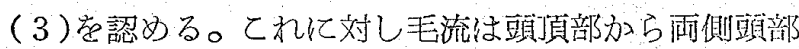
亿向う分離性毛流( a )で分裂線と殆んぞ同様の走间堂 示す。又後述する眼筑部上牛に存する毛流即ち外側に 向って斜走守る毛流 $(b)$ と ( a ) との間に毛流交叉 $(\mathrm{c})$ を形成してれは不整裂線( 3 ) の部分に相当する。眼筒

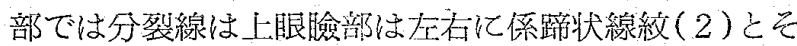

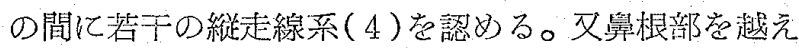
て左右上眼臉部鷹横走する線系(5)があり、てれに対 乙毛流は眼窩部上牛は眼裂々対して斜走 $(\mathrm{b})$ 乙上眼瞼 部は横走 $(d)$ する。眼裂より下牛は分裂線は横走線系 (6)总示し、毛流愋く䣄走 (e)する。㮌部の分裂線 はその上牛は横走線系群 $(7)$ であるが、下牛行くに 従つて斜走 (8)する。一方毛流は煩部全般に外側に向

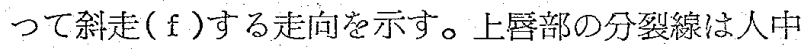
部の縱走線系及びその両側の縦走斜裂線系からなり (9)、一方毛流引人中加庄右に桩がる扇状の超

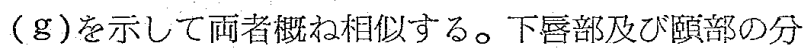
裂線は䨒状に左右に拡がる線系群(10)で占められ、こ の中の一部の線系は乱れている。一方毛流も全くてれ と同様の走向 $(h)$ 学示す。 


\section{c 胎坚 7 力月}

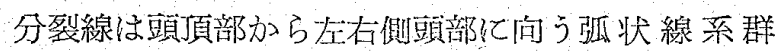

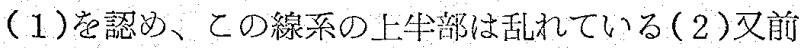
額部にほ中央部の高宗つた浩千の横走線系 (3) 觉認め る。な和後述の眼简部の半係蹄状線紋子該横走線系の 間に若干の不整裂線(4)が認方られる。これに対し毛 流は全て頭頂部汃ら両䀧頭部に向万分離性毛流( a )で 従つて上2/3部までは分離線と同一走向であるが、下 $1 / 3$ 部は分裂線に和ける前額部の山型の横走線系とは走向 を異にする。上眼臉部の分裂線は左右に牛係蹄状線紋 ( 万)が尚り該部の毛流 (b) と相似する。左右上眼臉部

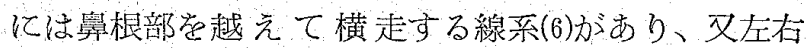

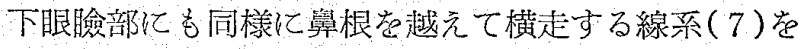
認める。一方との両眼臉部の毛流も分裂線と同一走向

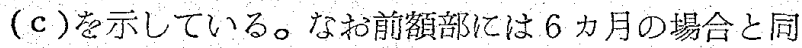
様䎲毛流交叉(d)があり、乙れ蛙不整裂線 (4) の部分 亿相当する。頓部の分裂線は䑁部加ら左右に斜走する 扇状線采群( 8 )でありとれ刘し毛流は縦走 (e)し ている。上唇部の分裂線は人中を中心化左右に扇 状に桩がる乱れた線系 (9)であり、一方毛流も同様に 扇状（f）学なしている。下唇部及び頣部の分裂線は扇 状線系群(10)でその線系の一部は乱れている。一方毛

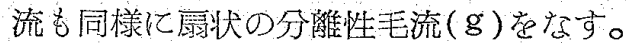

d 胎少 8 力月

前頭部の分裂線は頍頂部疮不降し前頭部の下方で正

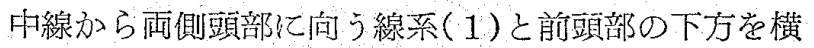
走する線系( 2 )とよりなる。乙れ亿対し毦流は頭頂部 加ら前頭部を下降し正中線加ら緩い角度で左右に分離 しながら眼窉部の上緣安で達する(a)、眼䆚部上牛の 分裂線は係蹄状線紋 ( 3 )を示し、乙れと前述の前頭部 下方の横走線系 (2) との間偌汗の不整裂線団 (4) 認める。左右眼窩部下牛は舅 根 部を 越光て横走線系 （5）方認められる。一方毛流は上眼睑部は外側に向っ て横走 $(b)$ しさらにその上方に外側に向う弧状の毛流 (c)力゙存在する。下眼臉部には外側に向つて横走する 毛流 (d)が認められる。䫅部の分裂線ははじ邓横走し やがて下方晌う線系群( 6 )走示すが、一方毛流も殆 んぞ同様々はじぬ横走し後㣪い弧状を画いて下降す

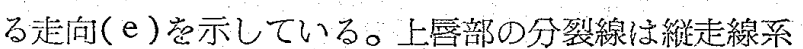
(7)で左右放ら人中に集る如き走向を示し一部の線系 は乱れている。乙れに対し毛流は同様に左右汃ら人中 に集宗方傾向を示しながら外側に行くに従い外方に刹

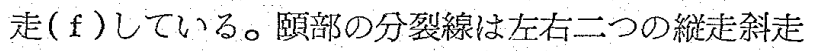
線系群 (8)方対象的に認められるが、一方毛流は扇状
に下方に拡がる走向 $(\mathrm{g})$ 范示している。

ii 側 面 (図 2 参照)

側面観は左右著しい美は認められないので右側面の み記載した。

a 胎览 5 力月

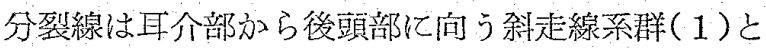
同しく頭頂部方々ら後頭部问う弧状線系群 $(2)$ 及び耳 介部を大きく畔繞する同心円性線紋 (3)と子りなり、 この 3 線系が相会する部位は若千の不整裂線( 4 ) 亿よ つて充される。てれに対し毛流は分裂線(1)の部分に のみ生じているが、これと全く同じ走行(a)である。

b 胎巟 6 力月

分裂線は頭頂部より後頭部に向う緩や少な弧状線系 群( 1 )及び頭頂部より耳介部に向与縱走線系群 (2) と よりなり、ての(2)線系は一部乱れている。一方ての 部の毛流は分裂線の走向と全く相似する(a)。又耳介 周团の分裂線は耳介を团緬する大きな同心刚性線紋

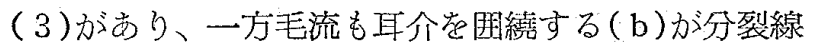
の場合の上うにその範囲は広くない。耳下腺咬筋部は 分裂線、毛流とも亿縦走するが分裂線䒺の一部は乱れ ている(4)。

\section{c 胎罗 7 力月}

分裂線は頭頂部を下降する斜走線系群(1) と後頭部 を下降する弧状線系群 (2)がありこの線系の一部は乱 れている。又耳介部の上部及び前部を横走する弧状線 系群 (3)办㒛如られる。又耳珠附近方ら上下に弧状線 系(4)があり耳介の一部沿って走っている。てれに 対し毛流は分裂線と殆んど同様に頭頂部少ら耳介部及

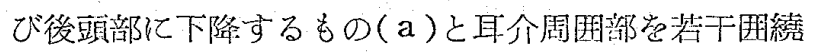
するもの(ら)とがある。

$\mathrm{d}$ 胎児 8 力月

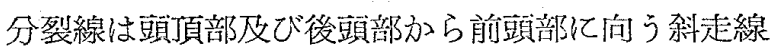
系群(1)方認められ、その間に一部線系の乱れている 部分 (2)办疗在する。耳部の上方仙弧状線系群 (3)が癹められる。一方毛流は頭頂部汃ら前頭部に向 つて走り、やがて弧状を画きながら後頭部に向うもの (a) と頭頂部汃ら後頭部化向うもの (b) と市り、耳介

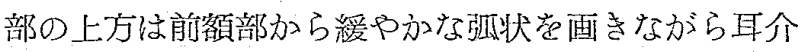

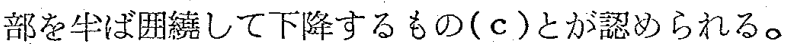
耳下腺咬筋部の毛流は縦走する $(\mathrm{d})$ 。

iii 上面 (図 3 参照)

a 胎児 5 力月

分裂線活頭頂結節間の広部定古す不整裂線団 (1) 
と、乙しから前頭部及び両側頭部に向う弧状線系群 (2)度び後頭部に向う縱走線系群 (3)で、この中、右 側牛分は䣄走縱裂線系群(4)を示している。乙れ亿対 U毛流は頭頂結節閒加ら前頭部に向うものは分裂線と 全く同様に左右儿分散する走向管示し (a)、頭頂結節 間から後部には未だ毛流方認められない。

b 胎览 6 力月

分裂線は頭頂結節聞の右 $2 / 3$ 克充す不整裂線団 (1) と

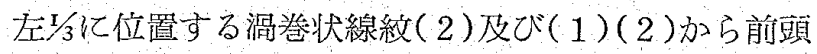
部、雨側頭部及び後頭部に走る線亲 (3)より形成され 前頭部に向与線系の上 $/ 2$ は乱れている(4)、乙れに対 し毛流は頭頂結節間より前磌部及び後頭部にをれぞれ 向万分滩性毛流 $(\mathrm{a} ， \mathrm{~b})$ 及び頭頂結節間の左奋の部分 孔ある左病性毛洞（散洞）とよりなる(c)。

\section{c 胎児 7 力月}

分裂線は頭頂結節間から前頭部、両側頭部及び後頭 部に下降する線系群 $(1)$ があり、頭頂結節間は不整裂 線団 (2)によって充され又後頭部に下降する線系群の 中、右側の一部は線系が乱れている $(3)$ 一一方毛流は頭 頂結䈟間広部の左側に放射性毛流( a)があり、それに

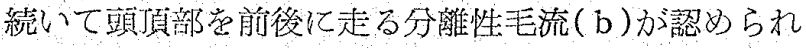
る。

\section{d 胎児 8 力月}

分裂線は頭頂結節間広部に不整裂線団 (1) 堂認め、 ここより前頭部、両側頭部及び後頭部に走る縱走線系 群( 2 )がある。な和不整裂線団 $(1)$ の左側には強く彎 曲する線系(3)か認められる。てれに封し毛流は頭頂 結節間応部门稍々左側てある右旋性毛洞 (a) 上り始末 り、乙れが周困に下降し右側は分離性活流 (b)となっ ている。

iv 篵 面 (図 4 参照)

a 胎完 5 力月

該部には未だ毛流か発生していない。

b 胎览 6 力月

分裂線は両耳介部の上方の附根を結ぶ線までは頭頂 部より下降する縦走線系群 (1) で下方に行くに従い正 中線加ら左右に分れる傾向を有し線系の一部は乱れて

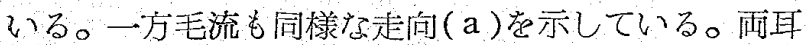
介部の附根を結ぶ線から以下後頸部に至る間は分裂線 は正中線汃ら左右们向与斜走横裂線系 (2) 范示し、乙 れ亿対し該部を縦走する毛流は後镇部で正中線加ら左 右化分離する倾向意有する $(\mathrm{b})$ 。

c 胎少 7 力月

分裂線は両耳介部を結ぶ横走線系 (1)及び該線まで
後頭部总縱走する線系群 ( 2) 存認め、(2)の線系の大 部分は乱れている。文(1)加ら以下は正中線汃ら左右

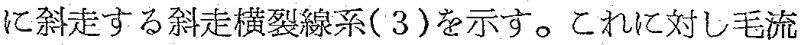
は後頭部汃ら後頸部に向つて下降し (a) 後頸部の正中 線で左右に分離する傾向を認める(b)。

$\mathrm{d}$ 䏩児 8 力月

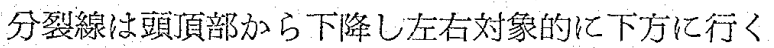
亿徒い稍々外側々向う緩やか子弧状の線系群(1) と雨 側耳:部总結ぶ緩い弧状の横走線系群( 2 ) とよりな り、（1）の線系は一部乱れている。一方毛流は頭頂部 占b後頸部门向って下降する走向 (a)を示している。

\section{2 小 插}

5 カ月より 8 カ月までの胎児を用いて頭部皮簏の分 裂線と毛流とについてその発育に伴う変化点実験観察 した。その成績を要約すれば次の如くである。

i 前 面 锶

前頭部の分裂線は 5 力月及び 6 力月の場合格毛流と 同様の走向学示し、 7 カ月抽よび 8 力月では上方 $2 / 3$ ま では分裂線と毛流は一致し、下方1/で眼筥部の近くの 分裂線は横走線系京し縱走乃至斜走する毛流と走问 を異にしている。又 6 力月、 7 力月及び 8 力月の前頭 部には毛流交冬が存在するが該部の分裂線は不整裂線 を示している。

上眼臉部の分裂線は各月共に丰流と相似し、下眼臉 部は 5 力月及び 6 カ月では分裂線は横走し毛流は斜走 するが、6カ月ではその斜走の度が緩やかになって分 裂線の走行任くなる傾向を示し、 7 力月及び 8 力月 では毛流す横走して分裂線と同様の走向觉示すと至 る。

煩部は 5 カ月では未だ毛流が発生しないが、6力月 以後に毛流を生じ分裂線と相似した走问を示す。

口部及び臨部は 6 力月以後に毛流を生じ分裂線と全 く同椂の走向学示す。

ii 㑡 面 钼

該部は耳介部周团以外は分裂線と毛流は各月とも概 ね相似した走向を示す。即ち 5 力月では分裂線は耳介 部周团を広く团䋽する同心円性線紋力゙認められるが該 部には毛流は未だない。6カ月に至れば分裂線は同様 に耳介部周囲な広く囲䋽する同心円性線紋となり、一 方毛流は同様に耳介部总囲繞するが、その範囲は分裂 線程広くない。7カ月になると同心円性線紋は大部分 消失し僅汃聑珠附近加らそれぞれ耳介部に沿って上 下する1〜2連の線系があるのみとなるが、一方毛流 は耳介部を広く因䌩するに至る。又分裂線は耳介部の 


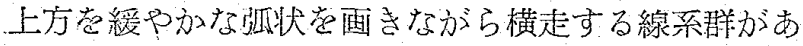
り該部范斜走する任流と走向を異にずる。

8 力月では分裂線は耳介部を国繞する同心円性線紋 はすで亿認められないが、耳界部上方觉横走する弧状 線系群及び耳介部後方范前下方に下降する斜走線系群 が認められ、該部の毛流と甚だ近似している。要之に耳 介部周用の分裂線は始めは広い範囲の同心円性線紋で あるが月令が加わるに従い狭くなるに反し毛流は始め

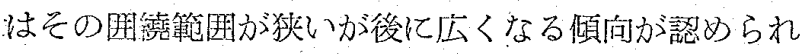
る。又 8 力月では耳下腺咬筋部の分裂線は主として横 走するが該部の毛流は縦走して異った走向起示す。な

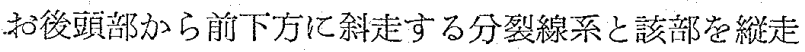
する毛流とは走向がー致しない。

\section{iii 上面锶}

該部の分裂線は各月总通じて毛流と相似した走行を 示ず。文頭頂結節間の広部に認められる不整裂線団は 該部の毛流か分離する处相当し、6力月に执いては 毛瀜に相当してそれと全く同樣な螺㳬状線系か認み られ、該線系は 7 カ月の毛渦部には認められず不整裂 線団のみとなる。8力月では毛渦部の分裂線は強く㱍 曲して毛渦の一部揌わしむる如き線系点示す部分が あるが、その他は不整裂線で充されている。即ちここに 和いても分裂線と毛流がある時期には全く一致し、西 る時期には一致しないという相互関係、換言すれば加 令的に相需り相反しながら互に成長して行く状態がよ

く微取される。

iv 後面 観

該蔀の分裂線は両耳介部の上の附根堂結ぶ線までは 両者全く同一の走问总とり、乙の線より下注両者異つ た走向觉示す。即ち分裂線は 6 力月では斜走横裂線系 であり、7カ月では横走線系に斜走横裂線系を混えて 和り、8 月月では主として横走線系を示し一方毛流は 縱走し下方に行くに従って正中線より左右に分れる走 向觉示している。

\section{3 背 部}

北部毛流は胎完 6 力月から発生しはじめ胎生末期に 和いても頭部毛流ほどに毛髪が長く発育しないので10 力月に至っても観察が可能である。従って 6 力月から 10力月に至る間の背部の分裂線と毛流との相互の関係 学突験覞察することが出来た。な扣観察の便宜上、後

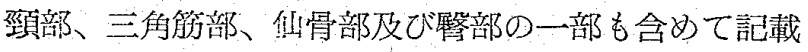
した。又発育の不充分な胎览に和いては各部位方成人 ほど判然としないので后甲上部、肩甲部、肩甲間部、
側胸部、季肋部、肩甲下部及び悀柱部の一部苍胸部背 面として又、側腹部、腰部及び毟柱部の大部分を腹部 背面として記載する。

a 胎児 6 力月 (図 5 参照)

胸部背面の分裂線は後頸部の斜走横裂線系群 (1)、 局申上部を横走する弧状線系群 ( 2 )、左肩甲部の緩や

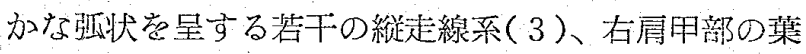

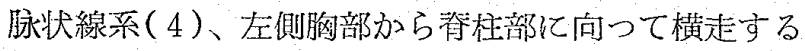
弧状線系群 $(5)$ 、右側胸部汃ら春柱部に向う横走線亲 群( 6 )、右李肋部汃らはじめは横走し後強く彎曲して 脊柱部に向う線系群 $(7)$ 及び左季肋部汃ら弧状を画い て脊柱泊う線系群( 8)汃らなうている。

腹部背面の分裂線は脊柱部中央稍々右寄りにある蝃 旋状線系 $(9)$ 之該線系に向って脊柱部の上方から斜多 亿下降する線系群 $(10)$ 、左右側腹部の上方加ら横走し 脊柱部直前で稍々上方に向う線系群(11)、左右側腹部 の下方方ら横走し脊柱部直前で互に下降方向をとる線 系群(12)、(11)(12) 雨線系群方隹柱部に相会する処に は菱形の線紋形成の傾问を有する線系(13)、背部最下 位に存する横走線系群(14)とよりなっている。乙れに 対し毛流は頭頂部の散渦から分散下降したものが後頸 部にて左右耳介部の後下方でそれぞれ毛流交叉( a 、 b) 学作り、その左側 の毛流交叉(a)加ら等合線(c) を作り右に筑曲しながらやがて正中線を下降し鉒柱部 中央稍々石寄に存する集渦 $(d)$ 亿達する。該集合線に は集瀜 $(d)$ K達する途中、左右の肩甲部汃らは稍々急 な傾斜で毛流 (e)が集合し、右側胸部及び右季牞部か

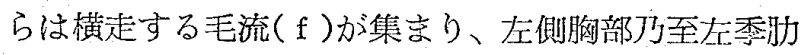
部からは弧状を画きながら集合しつつ、やがて 集渦 (d) 亿達する毛流( g)がある。な和右側の(e)は三角

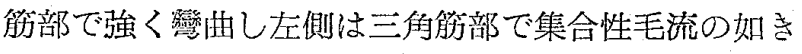
走向觉示すが、集合線は作らない。集渦(d)の下には 毛流交叉 $(h)$ 加認められ、 $(d)(h)$ 間の集合線仙左 右側腹部上牛から横走した毛流が集合線直前で互に上 昇する。毛流交叉(h)汃ら似骨部に至る集合線( i ) は 側腹部下牛加ら下晌つて斜走する毛流が集つて形成 される。

\section{$\mathrm{b} \quad$ 胎児 7 力月 (図 6 参照)}

胸部背面の分裂線は後頸部で正中線汃ら左右下方

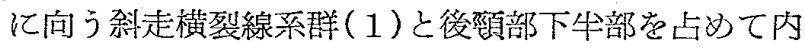
下方に向う斜走横裂線系 (2)とよりなり、(2)はやが て弧状の横走線系群 $(3)$ となって局甲上部移行す る。左右肩甲部认は弧状の緹走線系 $(4 、 5)$ 方゙あり、 
肩間間部の下牛から脊柱部のはじめまで正中線を下降 する線系の乱れた1 速の縦走線系 $(6)$ と談線系々両側 胸部及び季牞部汃ら斜めに上昇して集合する科走線系 群 $(7 、 8)$ 办認められる。(3)(4)(7)が相会する処 に不整裂線団 $(9)$ 名存在する。

腹部背面の分裂線は該部の大部分を占多る横走線系 群(10) と肛門部加ら左右側腹部の下端に向つて上昇す

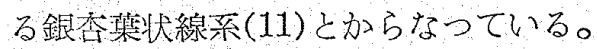

一方毛流は後頭部汃ら下降したものが分散線总作ら ずに正中線から緩やかて左右に分離しながら後頸部に 至る。の $(\mathrm{a}, \mathrm{b})$ 及び左右後项部分ら弧状を画きなか ら正中線に集合するもの $(c, d)$ 办古b、 $(a, b)$ 及

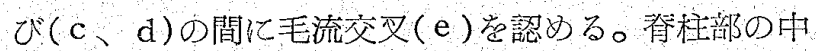
央には大きな集珮 (f)があり、その固团の毛流は両局

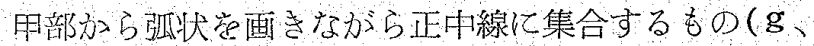
h）乙左側胸部加ら強い弧状を画いて正中線に集まる

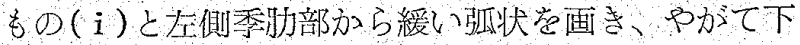
方で㳻走して（f)亿集まるもの（j），右側胸部汃ら 斜走して正中線化行くもの(k)，右柰牞部加ら横走し て(f)亿行くもの(1)とがあり、これら各毛流によつ て生した太い集合線 $(\mathrm{m})$ は左に属曲しながら集副( f に終っている。又(f)の下には毛流交文(n)があり、 てれは两側胸部加らはじめ横走し正中線直前加ら上昇 する毛流 (o) と左右側腹部汃ら肛門部に向う銀杏葉状 毛流 $(\mathrm{p})$ との間に生じたもののでる。

C 胎览 8 力月 (図 7参照)

胸部背面の分裂線は後頸部の横走線系群 (1)为、や がて肩甲上部焉横走する緩い弧状線系群 (2) となり (2)亿は一部線系の乱れが热められる。左右肩妇部か ら側胸部にか子けてはえれぞれ緹走する弧状線系群 ( 3$)^{\circ}$

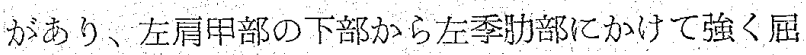
曲した坬状線系群 (4)就

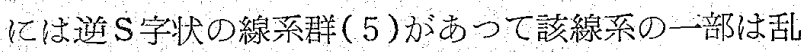
れている。な批(4)(5)は正中線上で相会している。 又 $(5)$ 、右側の $(3)$ 及び $(2)$ 方相会する处には不整裂 線団 (6)加諗められる。

腹部背面の分裂線は大部分は横走線系群 $(7)$ 亿よつ

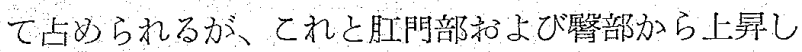
七銀否葉状線系 $(8)$ とが相会する処几不整裂線団 (9)

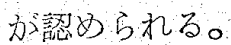

一方毛流は䏩部背面では後頸部套縦走する毛流( a) がやがて肩甲上部に至つて左右加ら正中線に集まる。 久左履归部を強い弧状を画きながら上昇しやがて下降 して正中線に向うもの(b)、左側胸部及び圭李肋部か ら緩やかな弧快を画いて正中線に问 $560(\mathrm{c})$ 、同様 飞右肩甲部加ら強い弧状を画いて正中線に向うもの (d)があり、右側胸部及び右李助部には棤走する毛流 (e)が認北られる。上述の各毛流はそれぞれ正中線々 集つて局明間部及び脊柱部范需状をなして下降し下方 に行くに従つて細少となり答柱部文の処で終る。

腹部背面は左右汃ら横走して脊柱部に集まる毛流 (f) 在以ってその大部分を占多られるが、雨側腹部下 方汃ら肛門部及び篟部に銀李葉状をなして下降する毛 流 $(\mathrm{g})$ 力諗められる。

\section{$\mathrm{d}$ 胎児 9 力月 (図 8 参照)}

胸部背面の分裂線は後项部に横走 線 系群 (1) があ り、てれが肩卌上部で緩やかな弧状線 系群（2）とな

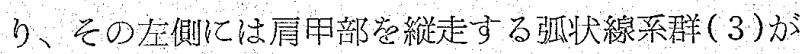

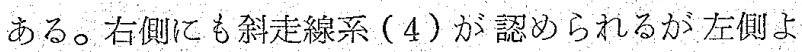

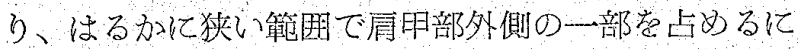
過ざない。左雇甲間部分ら左季肋部にかけて広い範用 に各々走向の違つた弧状線系群( $5 、 6 、 7 、 8$ )があ り（8）の季勅部側は横走斜裂線系となつている。右側 肩甲部の大部分及び側胸部、局甲下部、季叻部は主と して横走斜裂線系群 (9)亿ようて占妙られるか、季肋 部の外廓を弧状を画いて售柱部及び局用間部を上昇し 途中淘干線系の乱れを示しながら、やがて肩峰部附近 亿至る線系(10)があり、左側の (7) と該線䒺(10)はX 字状ななすが(10)の方かかで后不刘象である。

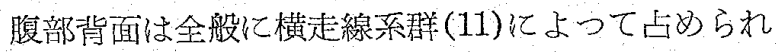
䀴門部及び繁部汃ら発した銀杏䈎状線系(12) と(11) と

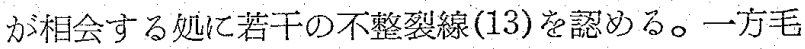
流は後頭部を下降したもの方後项部で正中線方ら左右 亿分離する毛流( a )となり、肩甲上部の両側加ら集合 しながら有甲間部の正中線に集まるもの(b)が認めら

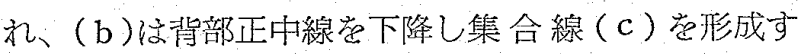
る。又左局甲部觉 S字状にはじめ上昇し後彎曲して (c) 飞流入するもの (d)、右肩甲部学斜走して (c) 亿 流入するもの $(\mathrm{e})$ ，右側胸部总涂走して ( c ) 亿流入す るもの(f)、左側腹部加ら结じめは横走し後弧状学画 いて替柱部集合線 $(\mathrm{c})$ 亿向うもの $(\mathrm{g})$ 、右側腹部を横 走して脊柱部に向うもの $(\mathrm{h})$ 、脊柱部の下方汃ら肛門 部及び慰部に扇状に下降するもの( i )が認められる。

な打 $(a)(b)$ 間及び $(i)(g)(h)$ 間の毛流交叉は明 瞭に譛得なかったが、てれに胎生末期になって一次 生毛方脫落して短いものと交換したためと観察不能々 
陌つたものと推定される。

$\mathrm{e}$ 胎少10力月（図 9 参照）

胸部背面の分裂線は後頸部に緩い弧状を画く横走線 系群(1)方あり、やがて层甲上部で横走する弧状線系 群(2)となる。(2)は一部線系の乱れを示す。左屃甲 部外側少ら左側胸部にかけては若干の縦走する弧状線 系( 3 )があり、その中一部は線系か乱れている。右局 甲部外側部即方三角筋部の一部には葉脈状線系 (4)が あり、その一部線系の乱れ示している。左肩甲部よ り肩甲䦓部及び側胸部にがて帯状の弧状線系 $(5)$ が 恰も局妇部の輸郭要く姐く下降して側胸部に向つて る。(3)と（5)の間には横走斜裂線系群 (6) が諗め いられる。又右側胸部分ら肩甲間部へ向う弧状線系群 (7)があり一部線系の乱れが認少られる。(2)(4)

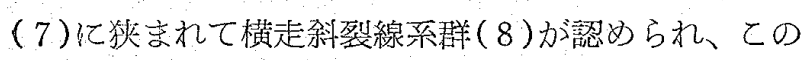
線系は側胸部の下仃では一部弧状線系 $(9)$ となる。

腹部背面纱横走線系群 $(10)$ 亿よって充される。な打 肛門部和よび㟲部からの銀杏葉状線系 (11) と、乙の横 走線系とが相会する处の線系は若干乱れを示している (12)。

一方毛流は网部背面では後项部を正中線方力ら左右に 分れながら、はつきりした分散線は作らずに下降する もの (a) と、肩田上部の雨側加ら肩用間部の正中線に

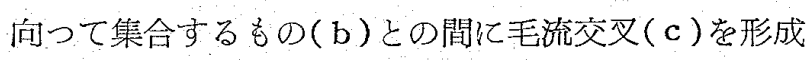
し(b)はさらに正中線学下降して佔骨部にまで至る毛 流 (d) となる。

左育甲部の外側々は緩い弧状を画いて縦走する毛流 (e)があり、右肩甲部の外側にも緩い弧状管画いて縱 走する毛流( f)力認められる。(e)はやかて稍々急な 弧状を画きなが肩甲部、次いで肩甲間部の正中線に 向う毛流 $(\mathrm{g})$ となり右肩甲部から肩甲間部の正中線に

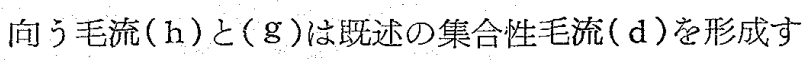
る。

腹部背面の毛流は左右側腹部汃ら腰部を経て正中線 亿向って互に斜走し (i )、脊柱部正中線に集合性毛流 (d) 起形成する。

\section{4小括}

6 カ月より10カ月宗での胎坚を用いて背部皮膚の分 裂線と毛流とについて、その発育に伴う変化を実験観 察したが、その成績を要約すれば次の如くである。

胎巟 6 力月では後頸部、肩甲下部及び両肩甲部外側 のそれぞれの分裂線と毛流はその走向を異にしている

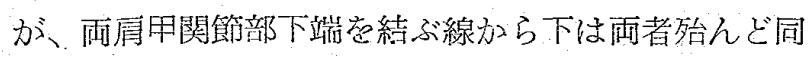

一の走向となり胸部背面の両外儧加ら互に集つて集合 線堂作りながら降し、やがて背柱部の毛渦（集洞） 亿至る毛流像と全く同様な分裂線系を柾作つている。

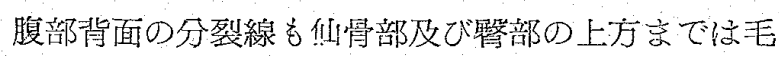
流と全く同じようと腹部背面の両外側方ら正印線と集 合する線系で、文集渦 (d)の下に存する毛流交灭 $(h)$

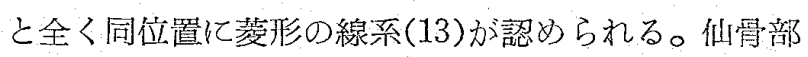

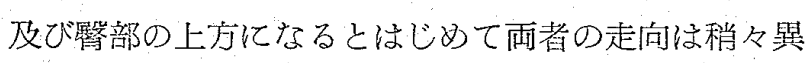
なり分裂線は蟥走 (14)し、毛流は正中線を集合線と吅 る葉脈状の走向觉とるに至る。即ち両腋窝壱結ぶ線と 腰部の下 $1 / 3$ 迄の間は分裂線と毛流は同一走向をとるの である。

胎児 7 カ月では分裂線と毛流が相似した走向觉とる 部位は、局妇上部の一部即ち ( 3 )と (d)、肩明部外側 で(5)と（）の一部、正中線を下降する 1 連の縱走線 系(6) と該部走る集合性毛流、缕部の一部总㮖走す る分裂線と該部を横走する毛流の部分、肛門部及び琴 部り腰部一の銀杏葉状の分裂線と毛流の一部分であっ て、これ以外の部位の分裂線と毛流は走向を翼てする る。ただ後頸部の分裂線で斜走横裂線系群 $(1)$ と鹳部 の毛流 $(\mathrm{a} 、 \mathrm{~b})$ は同一走向ではない方両外側て向う傾 向は同一のものと思考される。

胎児 8 カ月では分裂線と毛流が同一走向学とる部位 は、両側肩甲部、肩甲下部、側胸部、季肪部の大部 分、腹部背面の大部分であり、䀴門部及び㹂部から銀 杏葉状に上昇する毛流が瓷柱部毛流と相会する部分の 分裂線は不整裂線(9)で充されている。

胎览 9 力月では分裂線之毛流が同一走向をとる部位 は、局甲上部、両肩甲部外側、左局甲部の大部分即占 分裂線 $(3 、 5 、 6)$ 亿相当する毛流の部分 $(\mathrm{d})$ 及び腹 部背面の下牛分である。又䂓部及び䀴閒部の銀杏葉状 毛流が桼柱下端から発する部分の分裂線(13)は不整裂 線となつているが、その範囲は8カ月の場合ほど広く ない。

胎児10力月で分裂線と毛流が同一走向学とる部位は 肩甲上部の一部、両肩甲部外側及び両側腹 部の下方 で、6力月より10カ月宗での間で両者相似する部位が 最も少ない。ただ左肩甲部の分裂線(6)亿相当する壬 流の部分は同一走向ではないが、その傾向は同一の方 向として差交光なきものと思考する。

\section{5 組織学的所見 (写真参照)}

分裂線の方向は肉眼的に正確に観察することが出来 る。一方毛流も胎児 $5 \sim 6$ 力月が最も観察適してい 
るてとは論をまたないが、それは此䡆的のととであつ

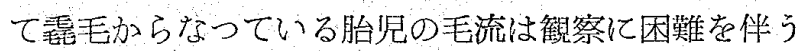
場合が少くない。依而研究の一助として組織学的钼察

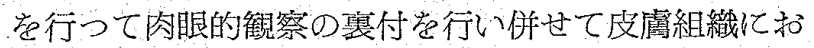
ける分裂線と毛流との状態を㮩察して次の所見党得 t。

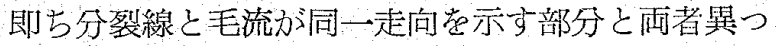

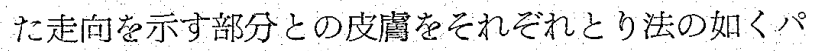

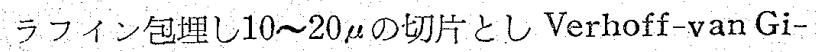
eson 染色を施した。切載方向は分裂線の走向に平行 に画直断施したもの及び皮膚面に平行に切線断を施 したものとした。即ち分裂線の走向と毛流方向が二致 する場合分裂線に平行に金直断施したもの（1)及び 皮膚面に平行に切線断を施したもの(2)，分裂線の走 向と毛流方向とが交叉する場合分裂線々平行に开直断 を施したもの(3)及び皮膚面に平行に切線断㠿施し たもの(4)都合 4 種類の切片標本を得た。その各々に つて記述する。

i 分裂線の走向と毛流方向が一致する場合

a 分裂線に平行に垂直断を施したもの（写真 1 )

毛根は紛断され真皮の上着には穿刺された悬汁が浸 闘して分裂されだ状沅がよく認められ、それが結合組 織主束の走向と一致して獚走しているのが観察され る。な扣毛球部に打しては明暸な横走縬維が毛球を載 せている状況観察するととか泏来る。

b 皮盧面に平行に切線断を施したもの（写真 2)

墨汁の浸潤によつて形成されたこ分裂線像か結合組織 主東の走向とよく一致しているのか認められ、又横断 された毛根の方向も分裂線像と同一方向に楕円状をと っているととが認められる。

ii 分裂線の走行と毛流方向加交叉方古場合

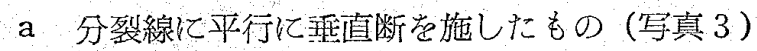

毛根级横断されその下方にあるものは毛根の横断像 のみで立毛筋、皮脂腺の横断像は認められず即ち真皮 深首からのものであるてと表現し、上方になるにつ 㣗て立毛筋或は皮脂腺の横断像を思わしむるもの認 め、乙れか頝皮浅層に由来するものであるととを証明 している。即ちての組織像は横断された方向と直角々 走っている毛流であるてとを物語つている。宗た真皮 浅屏には呀刺された墨汁が横走して浸潤している状㲘 がよく観察される。即ち分裂線は切載方向に一敨する ことを逆窥い知るてとが出来る。

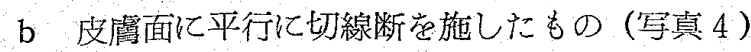

分裂線像が結合組織主柬の方向と一致して大作綐走 しているのか認められ、毛根の横断像は分裂線の方向

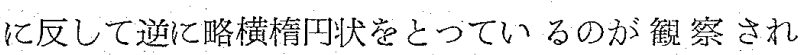
る。

以上の組織学的所見によって毛流の走向は肉眼的所 見と一致しているてと確めるてとが出来た。父分裂 線惊真皮浅周の分裂方向在現わし毛流真皮深尿乃至 皮下組織表㬝汃ら生ずる毛球の傾斜角度によって生ず るととは勿諭であるが、その毛流の方向は毛球を戴出 ている瀻維束の走向と全く一致するととを知り得た。

\section{IV 総括並に考揬}

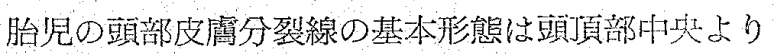
周国に分散する線系が前頭部、側頭部及び後頭部を下 降し前頭部では、やがて左存に分れて両側頭部に向 う線系、耳介部を䀧結する線系、顔面では眼筬部の上 下を横走する線系、眼简下部から煩部及び耳下脉咬筋 部に向う斜走線系、碩部の扇状線系とからなつて打

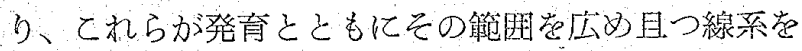
若干变えて行く。

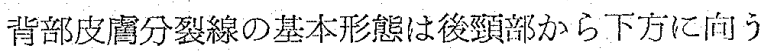
弧状線系、局甲部、側胸部及び僛腹部のそれぞ外側

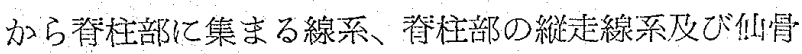
部の銀杏線状線系とよりなり頭部と同様化発育ととも にその筇囲を広め且つ線系を若干変えて行く。とのて とは先的が教室们いて各種脊椎動物の骨分裂線に 関して系統的、比較解剖学的研究堂なした結果、即方 分裂線は基本的にその骨の外形乃至形態に走配され る。能って発育に伴う変化を示すというととと全く同 様の結果意現わしている。

毛流の基本形態は頭部は頭頂絓節間の庄部に存在す

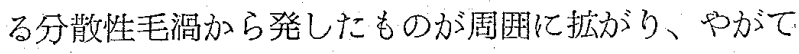
前頭部、側頭部及び後頭部を下降し、前頭部を下降し たものは、はっきりした分散線は作らずに左右に分れ て眼简部の值上で終り一部は耳前部を下降する。側頭 部を下降したものは耳分部学殆んど眮緼してさらに側 頸部を下降する。顔面では両内眼角及び左石眼臉縁に 源を発したものがそれぞれ上下に走り、上眼臉縁加ら のものは外側に向つて斜走して外眼角部に終るが該毛 流と前頭部を下降して左右に分机た毛流とが毛流父父 を形成する。両内眼角及び下腿睑縁加ら発したものは 頓部を外側に向って斜油降する。又下唇の下から 発した毛流は願部を扇状に下降する。背部は後頭部を 下降したものふふ後頸部で分離する。てれと雨肩甲部か 
ら弧状を画いて正中線に集合するものとが毛流交叉を

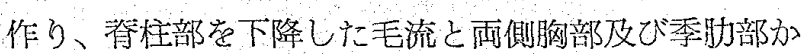
ら脊柱部に横走して集合したものが集渦学形成する が、場合によっては集瀜赏形成しないものもある。両 側腹部及び腰部分らは等柱部们つて斜走する毛流が あろ、乙れと前述の春柱部集渦のある場合はとの下方 に毛流交叉を形成する。文䎟側腹部及び腰部から銀杏 葉状に集合したものが尾骨中心に終る。しれらの諸毛 流か溌育とともにその範用党広めて行く。

上上の加き基本形態学有する胎児の皮温分裂線と毛 流とが発奇に伴って互にどのような変化を現わすかを 頭部は 5 力月より 8 力月まで、背部は 6 力月より 10 力 月までについて夷験観察したのであるが、分裂線及び 毛流雨者の走向が全く一致しない部位とその月令は下 記の如くである。

\section{1) 頭 部}

(a) $6 、 7 、 8$ 力月で後頭部の両耳介部の附根炽紹 ぶ線より下

(b) $7 、 8$ 力 月で前頭部の下 $1 / 3$

(c) 7 カ月で側頭部の耳介部上方及び耳介周四部

2) 背 部

（a） 6 力月で後頸部及び肩甲部少ら上腕への移行 部

（b）７カ月で左疦时部から上腕への移行部、胸部 背面の下 $2 / 3$ 、腹部背面の上 $1 / 2$

(c) 8 力月で後頸部、脊柱部、腹部背面の上至

(d) 9 力月で後頸部、脊柱部

(e) 10 力月で後頸部、春柱部、雨雇甲部

上記以外の分裂線と毛流は全く同一の走行をとる攻 或は、かなり近似した走向学とる。即ち全月命学通じ て互に走问の異る部位は後頭部の両耳介部の上の附根 を結ぶ線より下及びそれに続く後頸部のみであってそ の他の部位は、ある特期ては同一走向をとつて全く一 致する分或は近似した走向をとるが、全く相反した走 向をとるてとは柾るて少ないてとが判明した。

次不整裂線について観察するに頭部に扣けるこの 出現部位は、毛流と関連あると考えられるものは6、 $7 、 8$ 力の前頭部毛流交叉部に相当して認められる 不整裂線と $5 、 6 、 7 、 8$ 力月の雨頭頂結節間の広部 亿存する分散性毛流の部位に相当して認方れる不整 裂線団があり、背部では $8 、 9 ， 10$ 力月の们骨部と等 柱部の毛流とが相会する部分に認好られる不整裂線 ( 9 力月、10力月の例) 万至不整裂線団 ( 8 力月の例)
がある。乙れらの不整裂線は何れも毛流力強く交文す るか或は衝突する部位、又は強く分離する部位に認め られるのであって、てのてとはわか漖室に扔いて数年 来なされた各種動物の骨の分裂線の研究成果之同様に

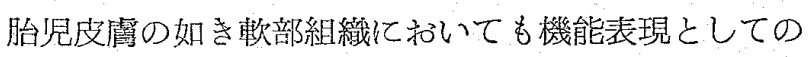
不整裂線が出現するととを裹書きするものであり、と れ埌皮膚の内的発育力の衝突が毛流像ととも亿表現さ れてものと考えるととが出来る。

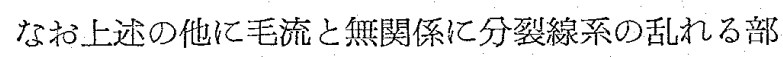
值がある。即ちその主なものほ頭部では 5 力月側頭部 (4)、6力月頭頂部の前方 (4)、前頭部 (1)、耳下腺 咬筇部 $(4) 、 7$ 力月前頭部 $(2)$ 、頡頂部の右後部 $(3)$ 、 8 力月側頭部 $(2) 、 5 、 6 、 7 、 8$ 力各月の後頭部 であって、てれは胎巟皮虞が幼弱なためひ生じたもの と考光られるが、な打存細に観察すればての線系の乱 れる籁用並びに强さは 7 カ月に揖いて最も著しく 8 カ 月に至れば梢々整然となる傾问を有する。背部で毛 流と無関係化分裂線系の乱れる部位は 7 力月右肩甲部 の不整裂線団( 9 )、8 力月右肩甲部の不整裂線団 (6): 9 カ月脊柱部の右側の線系の乱れ (10の一部) であ り、ての場合に扔いても頭部と同様に胎生未期になる に従つて線系が整然となる傾向がある。てれは内的発 育力の衝突に伴って生じた機能表現が毛流像と別個に 真皮表風に現われたと解するととが出来る。さらに敷 衍すれば皮膚発育の文化が著明となり真皮表首部とと の深層乃至皮下組織表層部之の発育方向が異るためで あると思われる。

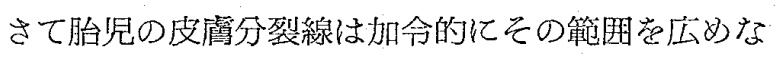
がら若干線系を変えて行くことは既述したが、このて

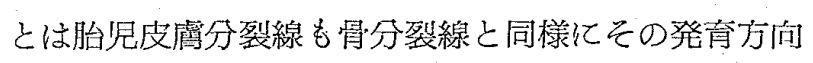
の示現であるてとが明らかであるが、瞄述の如く胎児 毛流と皮細分裂線はその発育過程に和いて相互の走向 は或特期に执いては全く相似し、或る時期に和いては 相似しない部位もあるが、その際でも走向が全く相反 するととは槧娐ない。即ちとのととは毛流も分裂 線と同様に皮膚発育方向の示現であるととを知るので ある。又胎児皮膚の不整裂線が姿々毛流との関連に打 いて出現することは、胎児皮覻にも骨質と同様に防禦 反応としての直接的な機能表現を現わす場合があると 考えられる。

上述の肉眼的諸所見をさらに組織学的に観祭すると 先づ毛流の方向と分裂線の方向との相互関係は肉眼的 所見と全く同一であるととを確め得た。次传膚分裂 
線は真皮の比輘的上層の分裂方向を現わすが、毛流は 毛根の傾斜角度にようて形成されその毛流方向の加令 的变化は毛球の接する層即ち真皮の比輅的深層乃至皮 下組織表序の絽合組織の発育方问によつて渗定される ものであると考えられる。徒っててのととが分裂線と 毛流とが登育過程に执いて互にその走向か㳠似したり 或ば離反したりする原因を成すものと考える。

\section{$\mathrm{V}$ 續論}

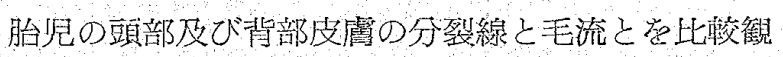
察した。即ち毛流の钼察しやすい月命として頭部は 5 カ月よb8 カ月までの、背部は 6 力月より10力月まで の胎忨を用いて分裂線と毛流の相互の関係を扣令的に 観察して次の結果を得た。

1）各月命蕊通じて分裂線及び毛流両者相似した走 向它示す部位は、前頭部の上 $2 / 3$ 、眼䆚部の上牛、側頭 部、頭頁部、後頭部の両耳介部の上の附根を結ぶ線ま て、下唇部及び願部、口部の上牛、腹部背面及び似骨 部である。

2) 初わは互に走向が異なり発育する亿従つて相似 乙て来る部位は、眼筒部の下牛、耳介部の周园、煩部 及び有明上部である。

3）発育過程の或る時期にのみ走向の一致する部位 並びにとの月令は、頭頂毛瀜部、脊柱部及び鋚柱毛瀜 部でそれぞれ 6 カ月

肩甲部より肩甲間部及び肩甲下部に亘る部位で 6 カ 月、8カ月である。

4）全月例然通して互に走向の異なる部位は、後頭 部の両耳介部の上の附根を結ぶ線より下で後頸部に移 行する部分のみである。

5) 不整裂線と毛流との関係は特異なすのがある。 即ち頭頂部の中央市ら周团に毛流各分散する部位、前 頭部の气流交叉の部位、仰骨部の銀杏葉状毛流と背柱 部の横走する毛流とが合する部位の分裂線はとれぞれ 不整裂線を旺する。

以上の所見より胎少皮膚の分裂線と毛流は互に加令 的に变化し、その発育過程に扔いて相互の走向は或る 時期と扔いては全く相似し、或る時期と扣いては相似 しない部位もあるが、んの際和いても走向方全く相 反するととは極すて少ないとと知り得た。な和組織 学的に観察すると皮膚分裂線は真皮の比軦的上層の分 裂方向点現わすに反して毛流は毛根の傾䣄角度によつ て形成され、その毛流方向の加命的変化は毛球の接す

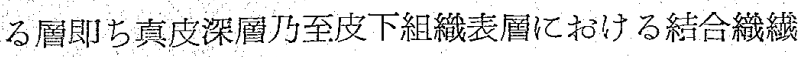

維走向即ちその発育方向によって決定されるてとが観

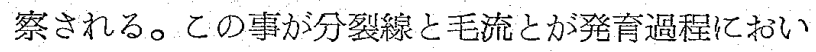
て互にその走向が近似したり或は離反したりする原因 をなすものと思考される。てのよう胎览の毛流方゙皮

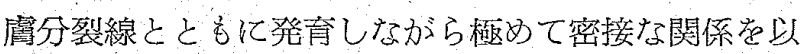
て互に変化する事実は胎少の毛流も文、分裂線之同様 亿皮膚発育即与真皮深首乃至皮下組織表層に和ける結 合織の発育方向定示しているものであり、页不整裂線 と毛流との関係即ち走向の異なる毛流の相会する部 位、或は毛流が互に強く分離ずる部位に不整裂線が現 われる事実は毛流る又皮膚分裂線の機能表現之深い関 係があるというととが出来る。

な和毛流て個体差があるととは勿論であるが、各個 体の分裂線と毛流の発育過程付和少相互関係觉追求

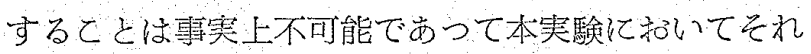
骂指摘するととは出来ない。

稿学終るに当り終站御息篤に御指導、御校閲下され た恩師中山種秋教授に深謝する。

\section{文献}

1）金関文夫、忽那將带：生体学概諭、人耀学先史 学諈座、2 巻

2）須田昭義：日本人の皮符及び毛繋、人類学先史 学請座、 1 巻

3）山满克已：日本人胎览毛線の形態认就て、解剖 学椎誌、 3 巻、 3 号 (昭 5 )

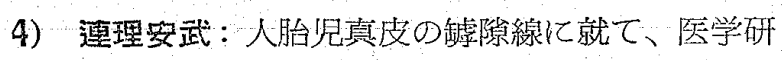
管、22浩、10号 (昭27)

5）福茾広之輔：皮膚結締組織装置の構造に就て、 医学研究、10巻、4 号 (昭11)

6）藤田恒太郎：生体観察

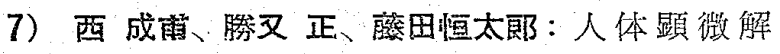
剖闵譜

8）皆見省玨、樋口潇太郎：皮膚病性病学

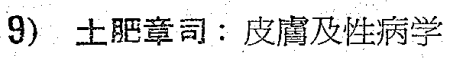

10）中山粞铁：骨分裂線特に不整裂線の意義、九州 歯会誌、11巻、1号 (昭32)

11）中山檑积、大稆忠雄、上村一雄：家鬼骨の分裂 線に関する研究、第 1 編椎骨及び别骨の分裂線に 就て、九州䒩科大学第一解剖学榇堂諭文集、第 1 号 (炤27)

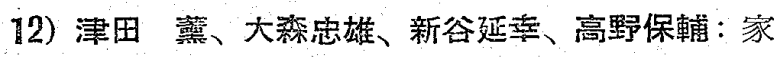
乘骨の分裂線认関する研究、第 2 編四渎骨の分裂 線に就て、九州歯科大学第一解剖学教室論文集、 
第 4 易 (明29)

13）中山程秒、上村一瞧：家䳕骨の分裂線に関する 研觉、第 1 螎、肋骨の分裂線に就て、九州歯科大 学第一解剖学教案論文集、第 4号（昭29）

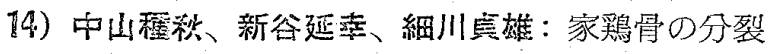
線に関する研究、第 2 編後肢骨の分裂線に就て、 九州岪科大学第一解剖学教室論文集、第 4 号（昭29）

『5）細川賏雄：家鵎骨の分裂線に関す石研究、第 3 編家鵎骨前肢骨の分裂線に就て、熊本医会誌、28 巻、12号 (昭29)

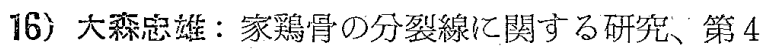
䋩家鶏椎骨の分裂線に就て、熊本医会誌、28巻、 12 号 (昵29)

17）中山程视、中崎 记：山羊頭笽骨の分裂線に就 て、熊本医会誌、28巻、12号（昭29）

18）細川点雉：家鬼骨の分裂線に関する研究、第 3

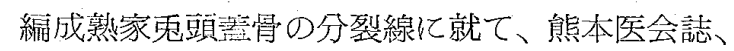
29巻、10号（昭30)

19）細川貝雄：家䳕骨の分裂線に関する研究、第 5 編成熟家鵎頭瓂骨の分裂線に就て、熊本医会誌、 29巻、10号（昭30)

20）藤下 晃：「あしか」の骨分裂線に関する研 兑、第 1 編肋骨の分裂線に就て、熊本医会誌、29 巻、11号（昭30)

21）藤下 晃：「あし加」の骨分裂線に関する研 安、第 2 編肩甲骨の分裂線に就て、熊本医会誌、 30巻、補 1 (昭31)

22）木村喜久郎：犬克用いての骨発夌飞伴う分裂線

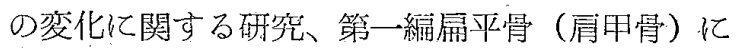
打ける変化、熊本医会誌、30巻、補 1 （昭31）

23）細川点雄：犬頭瓂骨の発育に伴う分裂線の变化 飞就て、熊本医会誌、30巻、尃 1（昭31）

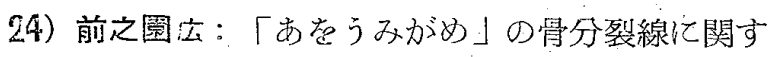
る研究、熊本医会誌、30巻、補 4 (昭31)

25）藤下 晃：「あしか」の骨分裂線に関する研 充、第 3 編㓩肢骨の分裂線に就て、熊本医会誌、 30 怣、補 4 (昭31)

26）藤下 晃：「あしか」の骨分裂線に関する研 究、第 4 螎後肢骨の分裂線に就て、熊本医会誌、 30 巻、裾 4（昭31）

27）小山次雄：大腿骨骨折の治痖機転に伴う分裂線

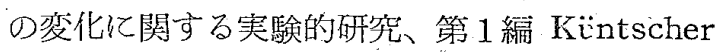
氏髄内固定に晾㚈る場合、熊本医会誌、30巻、補

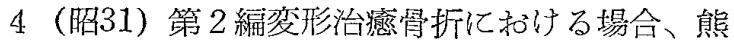
本医会誌、30巻、補 4（明31）

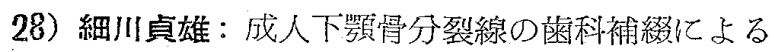
変化任関す石研究、解剖誌、31巻、5号(炤31)

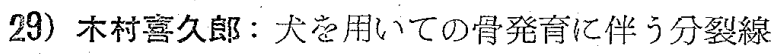
の変化関する研究、第 2 編長管状骨 (上腕骨) そ打ける変化、熊本医会誌、30巻、12号（昭31）

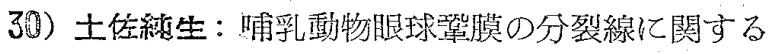
比較解部学的研究、熊本医会誌、30巻、7号（昭 31)

31）竹内 音：火の科軟骨、翰状軟搰、椎間门板 及び股間節軟嗗分裂線の発育に怑う変化に関する 研究、第 1 螎犬の状乾骨分裂線の発育に伴う変 化に就て、熊本医会誌、30巻、12号（昭31）第 2 編大の翰状軟骨分裂線の発育に伴う変化に就て、 熊本医会誌、31巻、3号（昭32）第 3 編大の股関 節軟骨分裂線の発育に伴う変化化就て、熊本医会 誌、32巻、1昂 (啒33)

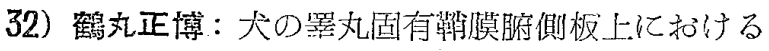
分裂線の年今的変化化就て、未発表

33) Eurkard: Ueber die Hautspaltbarkeit menschlicher Embryonen. Arch. A. Anat. u. Physiolog. Abt. (1903)

34）大栄忽雄：犬倠骨の発育に伴亏分裂線の变化に 就て、九州萪会誌、11巻、5号 (昭32)

35）任藤信正：犬下磒骨の発育に伴う分裂線の変化 に就て、九州歯会誌、12巻、2号（昭33）

\section{写 䉛 說 明}

何れも Verhoff van-Gieson 染色、桩大 $61 \times$

1) 縦断された毛根 $(\mathrm{H})$ 、真皮上層の㠘汁の浸潤し

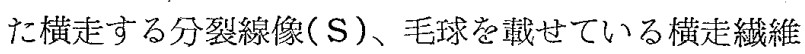
(F)、横走する結合織 $(\mathrm{B})$

2）横断された椿川状の毛根 $(\mathrm{H})$ 及びてれと同方向 の墨汁の浸潤した分裂線像 $(\mathrm{S}) 、(\mathrm{H})$ 及び( S )と同一 方向住走結合織 $(B)$

3）真皮深層汃らの毛根横断像 $(\mathrm{H})$ 、真皮浅風方 の立毛筋或は皮脂腺空伴つた毛根横断像 $\left(\mathrm{H}^{3}\right)$ 、墨汁 の浸潤した分裂線像 (S)、横走する結合織(B)

4）横铒された棈川状の毛根像(H)及びてれと交必 方向の墨汁の浸潤した分裂線像 (S)、（S )と同一方向 亿走る絓合織( 

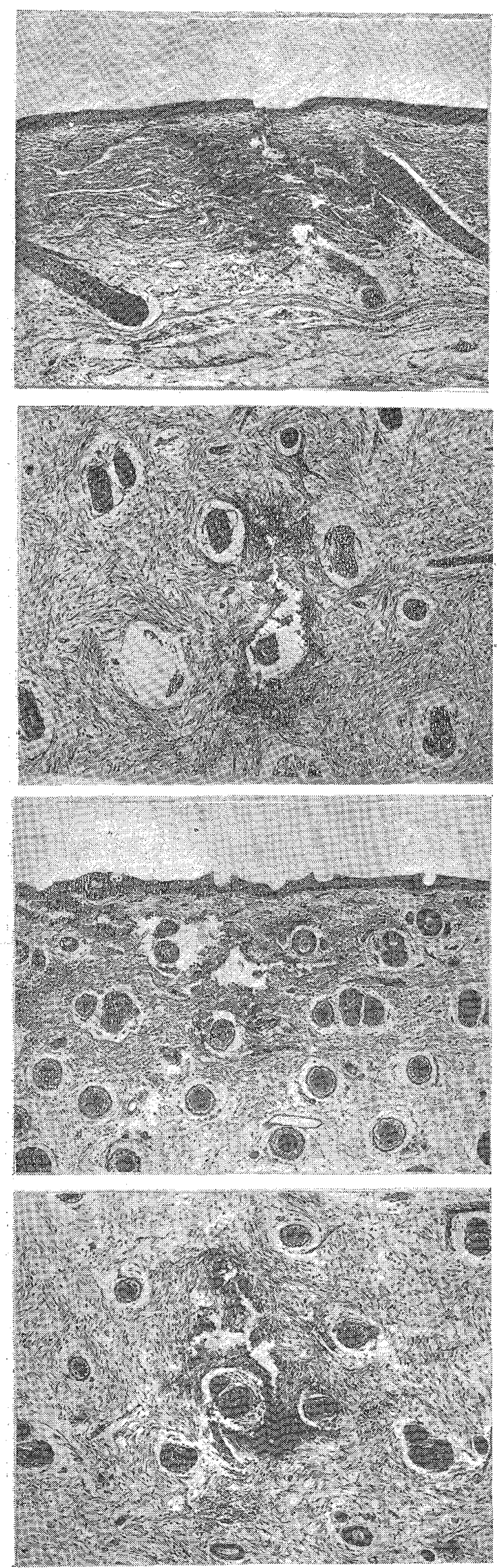
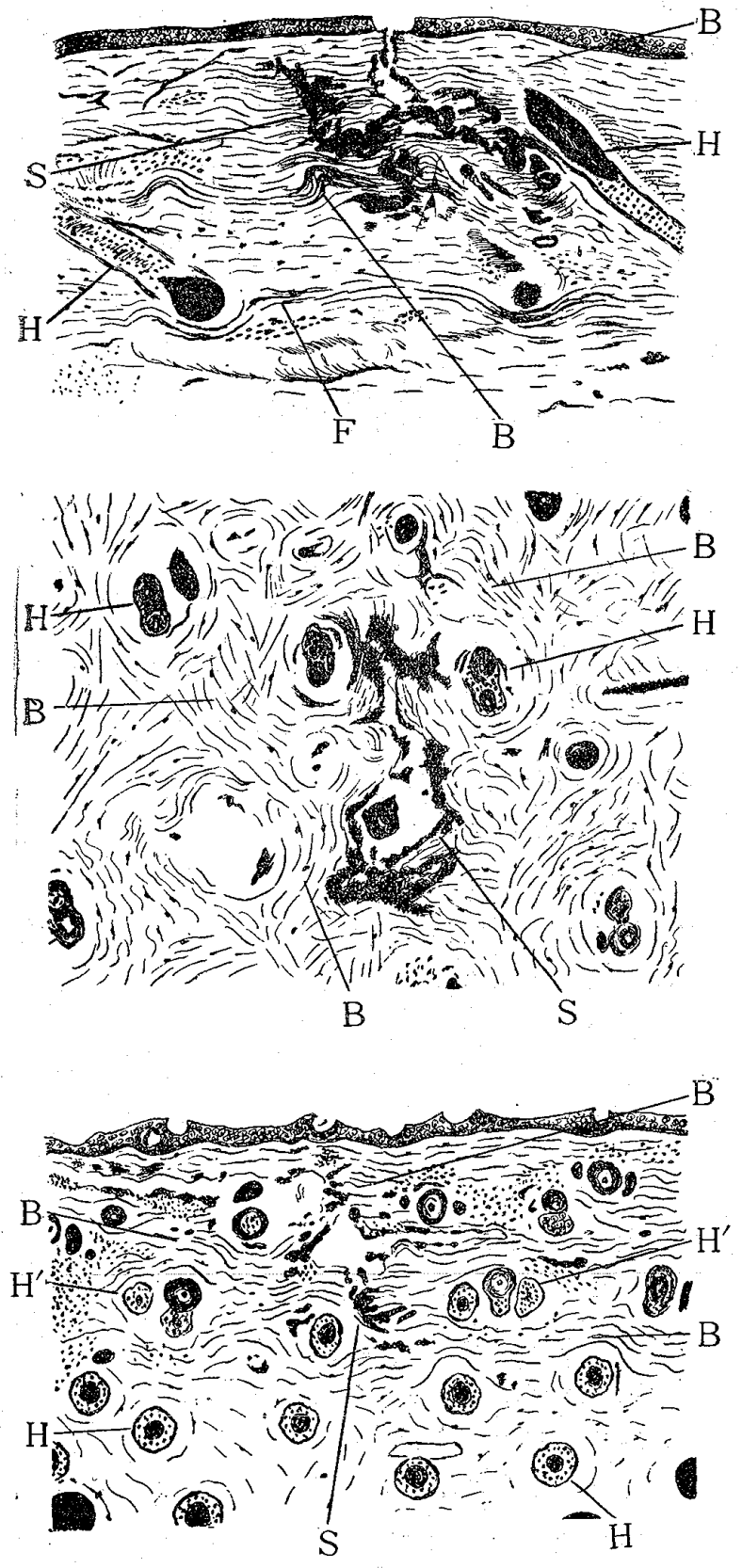

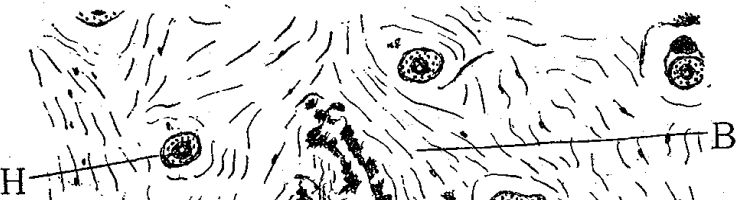

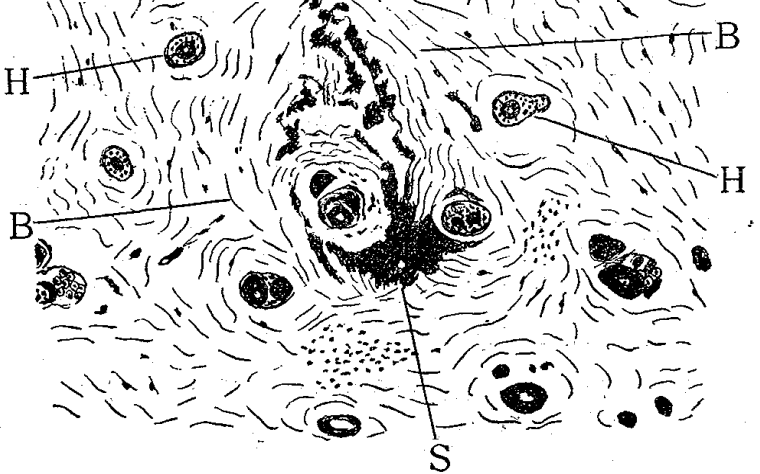



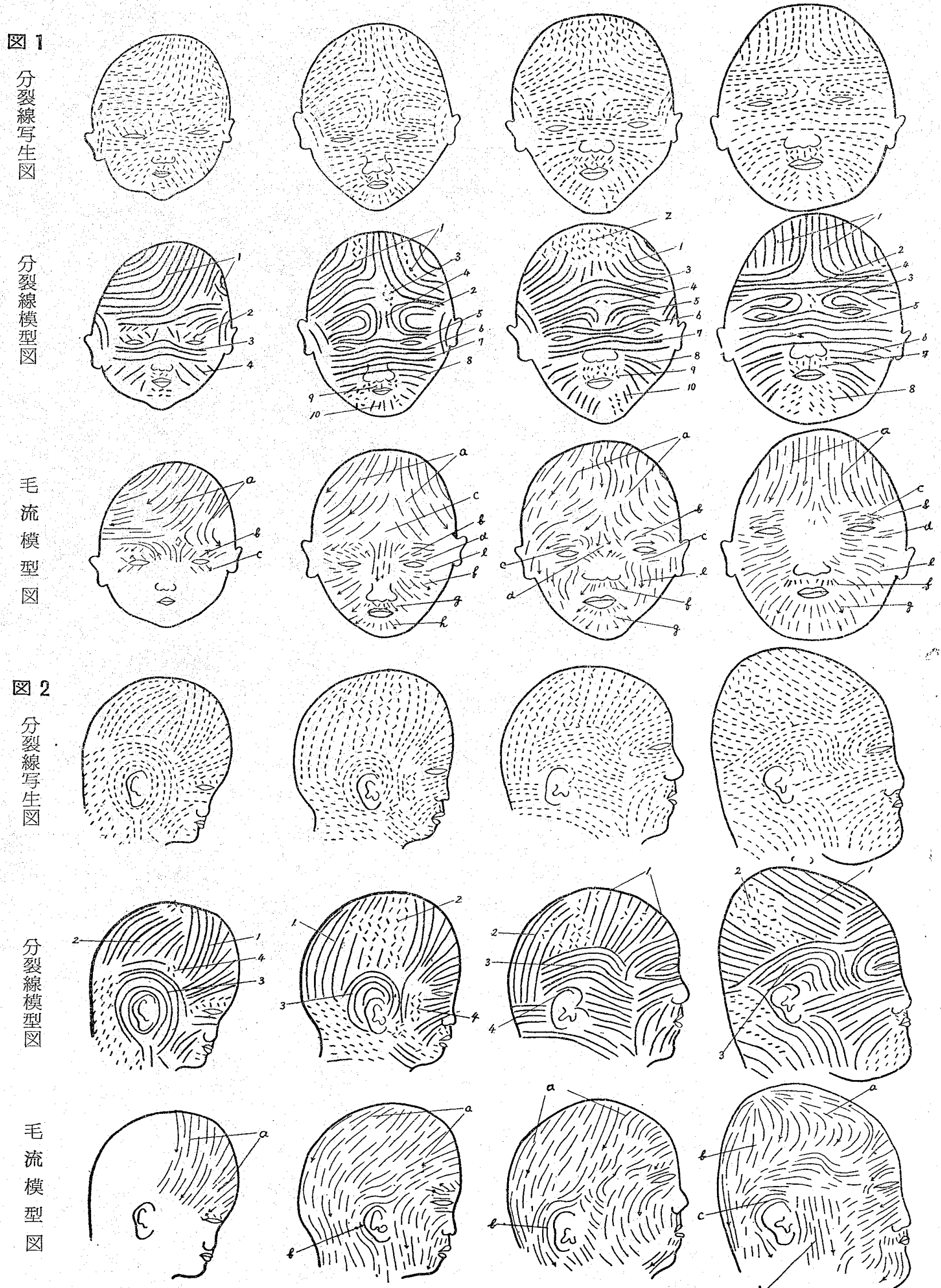

5 ヶ月

6 ケ月

7 ケ月

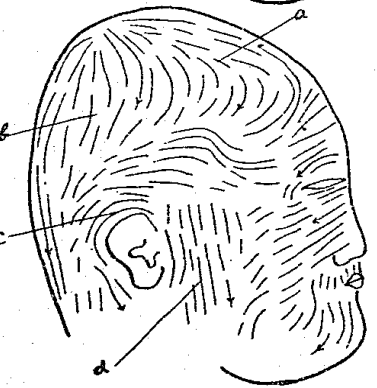

8 ケ月 
图 3
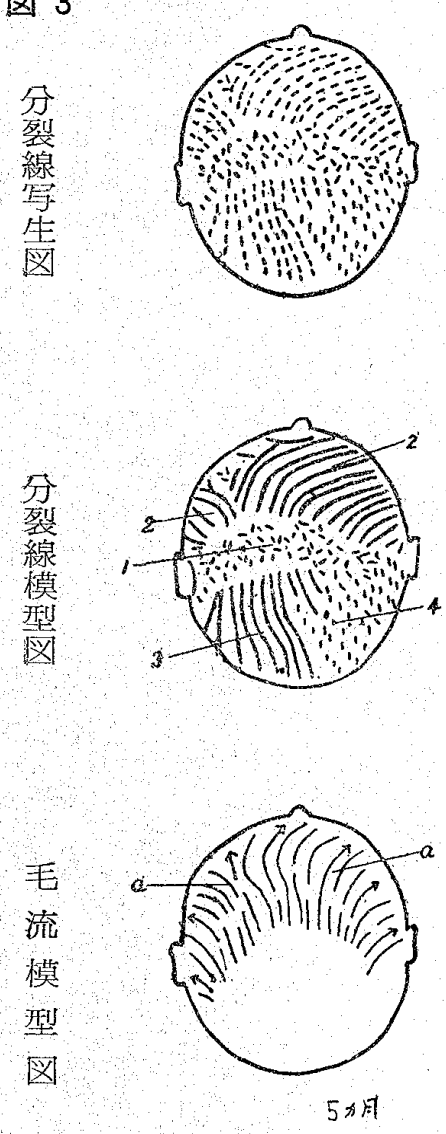
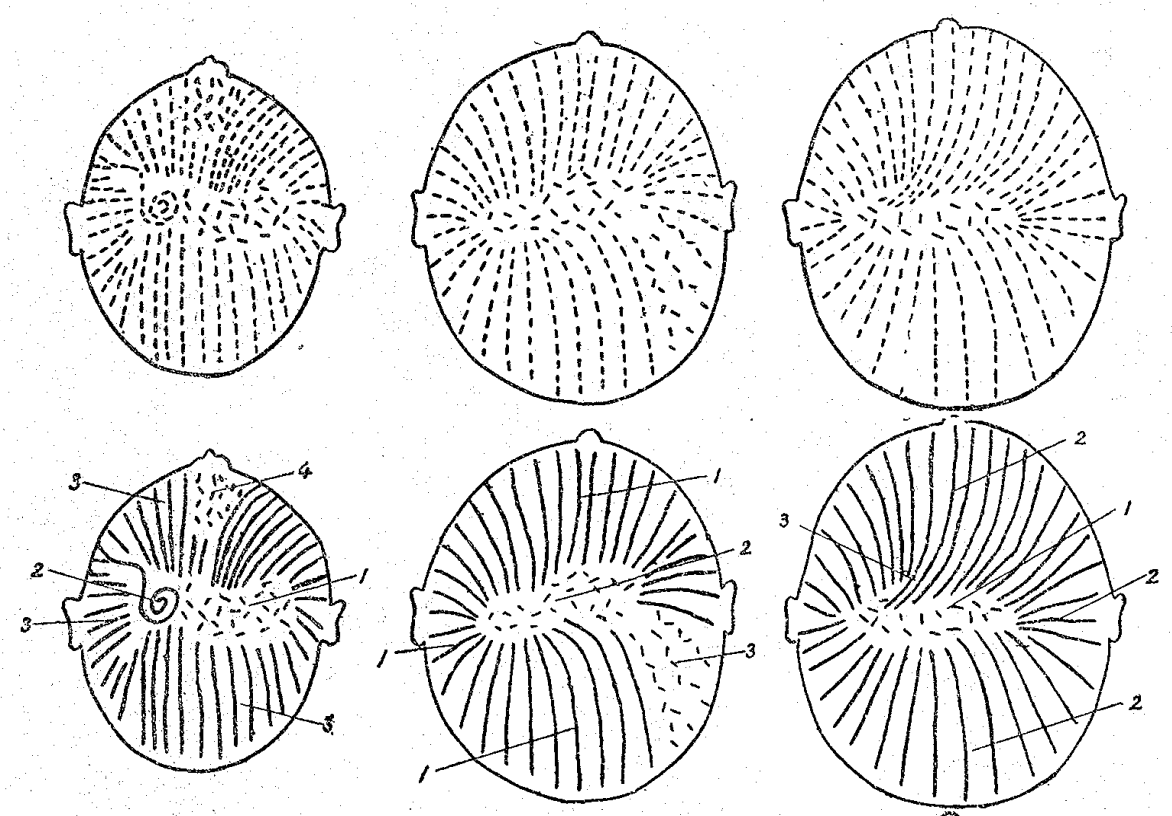

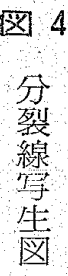
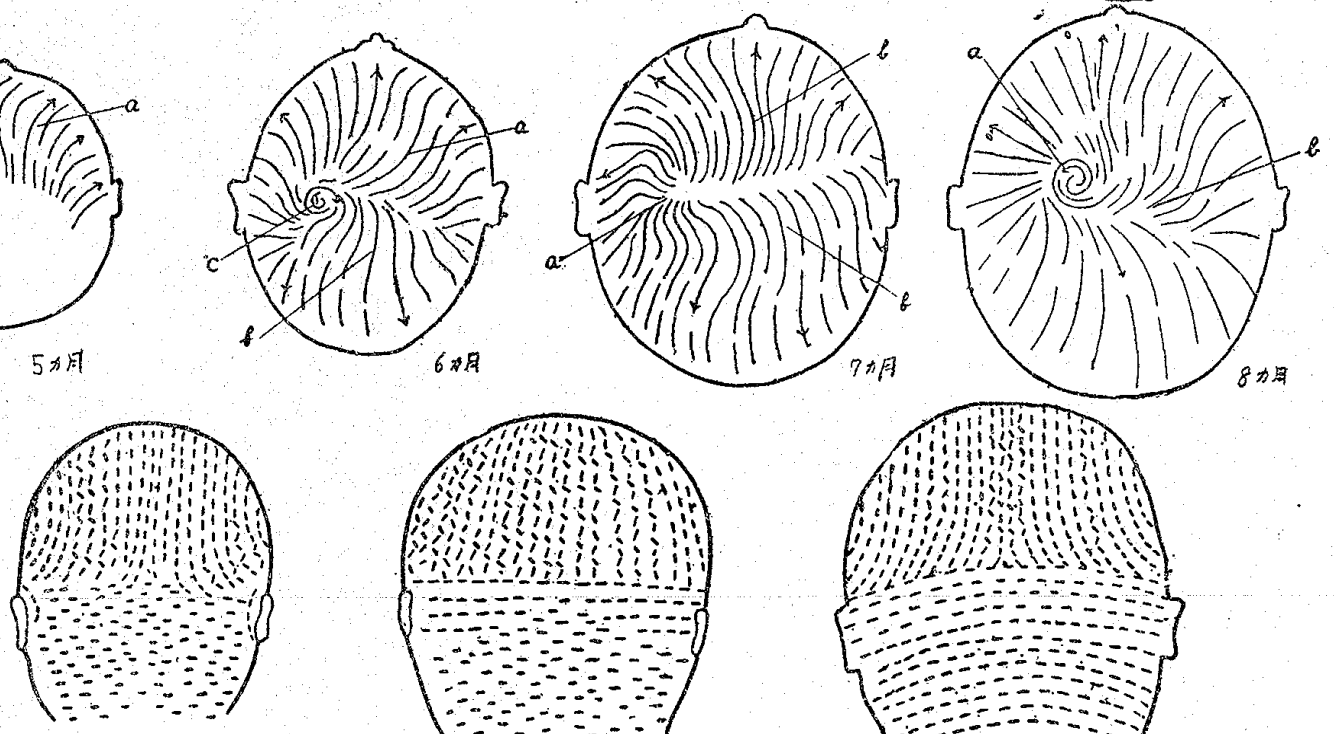

等
緮
模
型
図
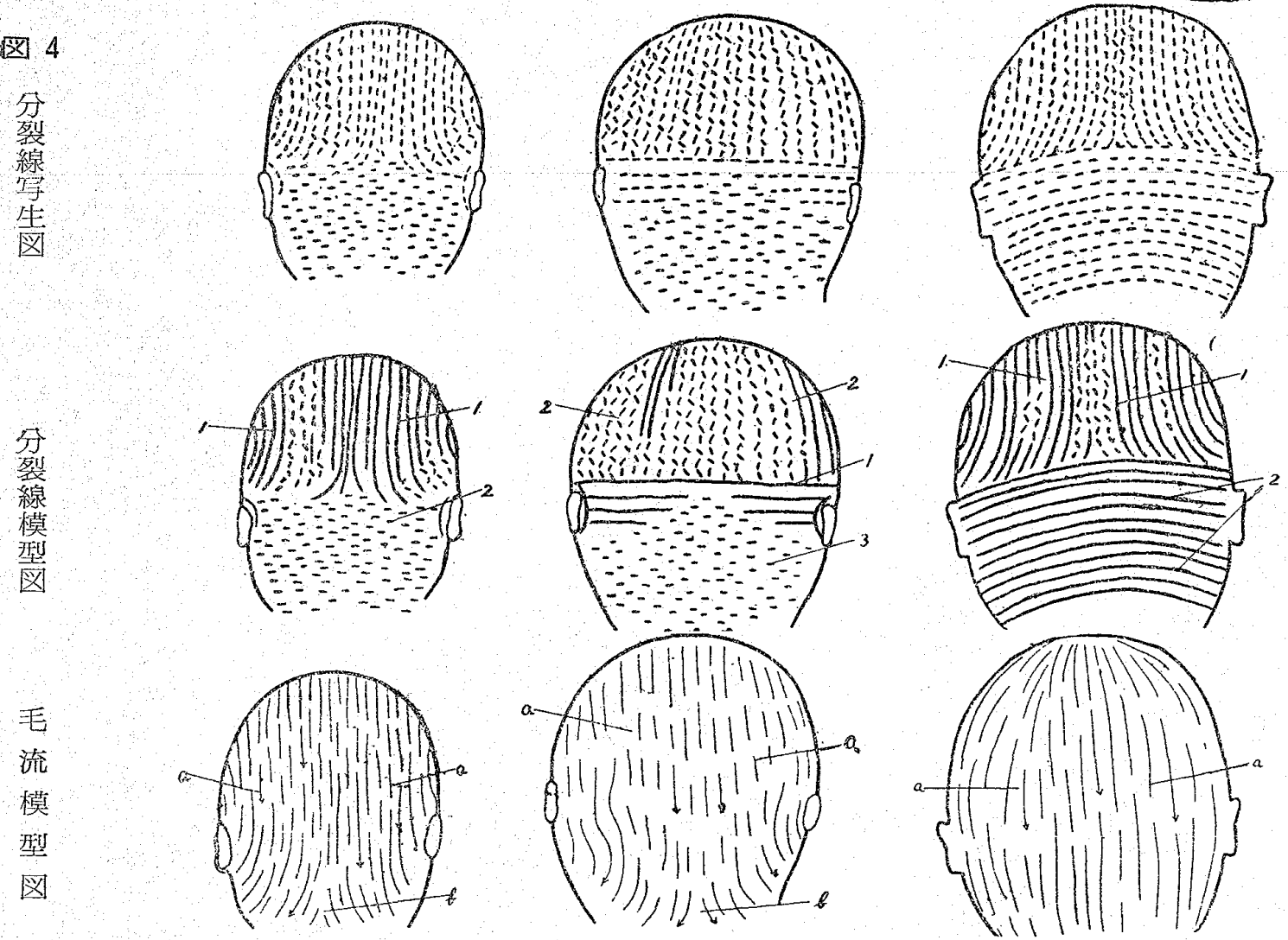

6 万月 月

7. ケ月

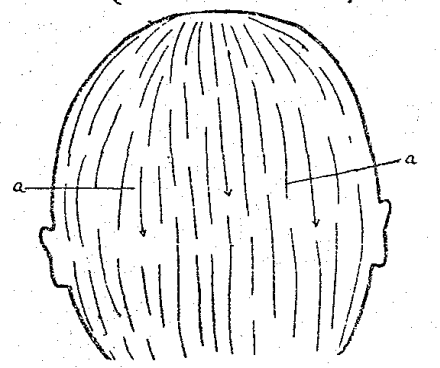

8 ケ月 
図 5 背 部 6 ケ月

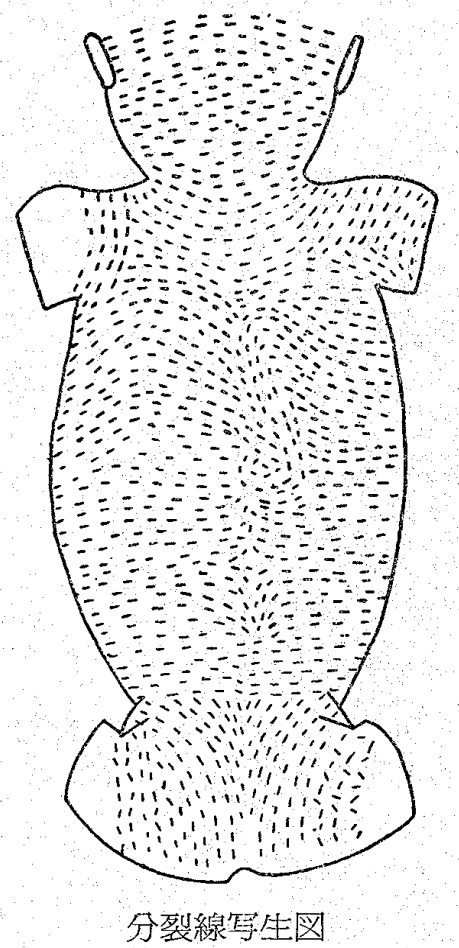

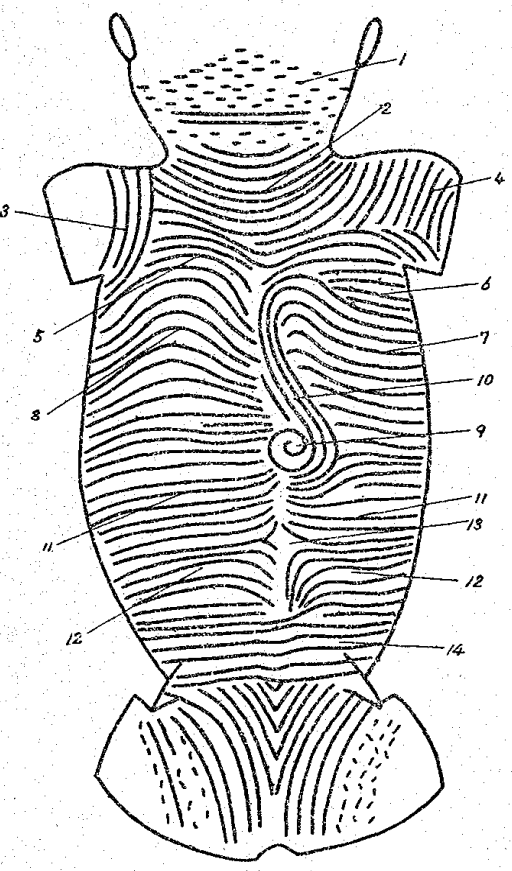

分裂線模型図

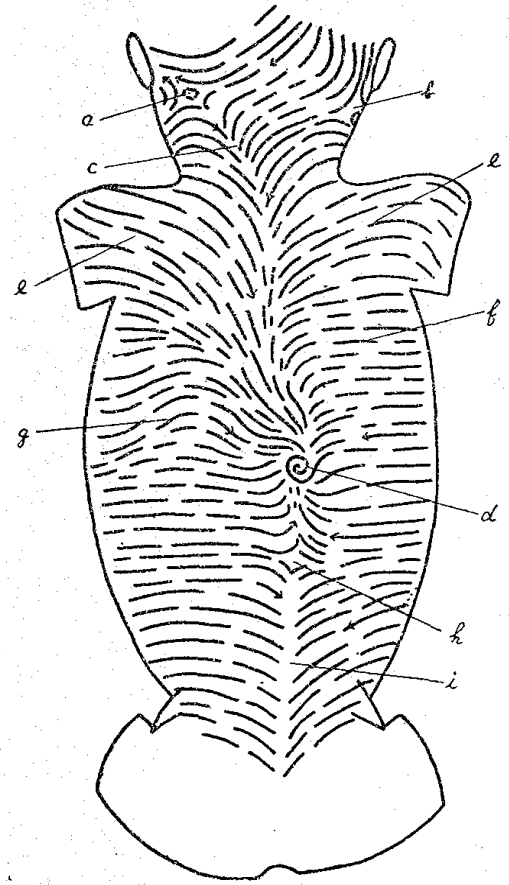

毛流模型図

図 6 背 部 7 ケ月
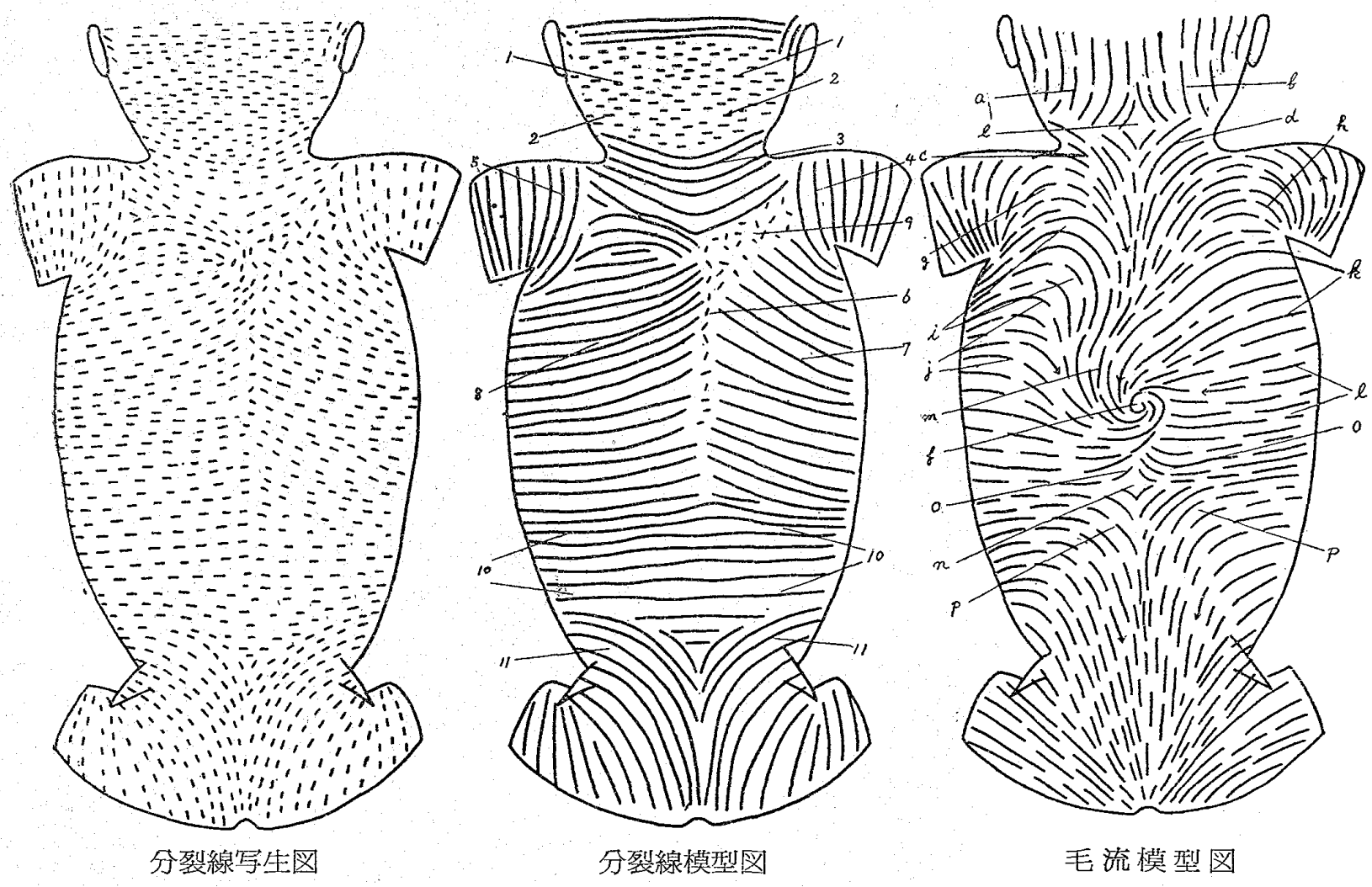

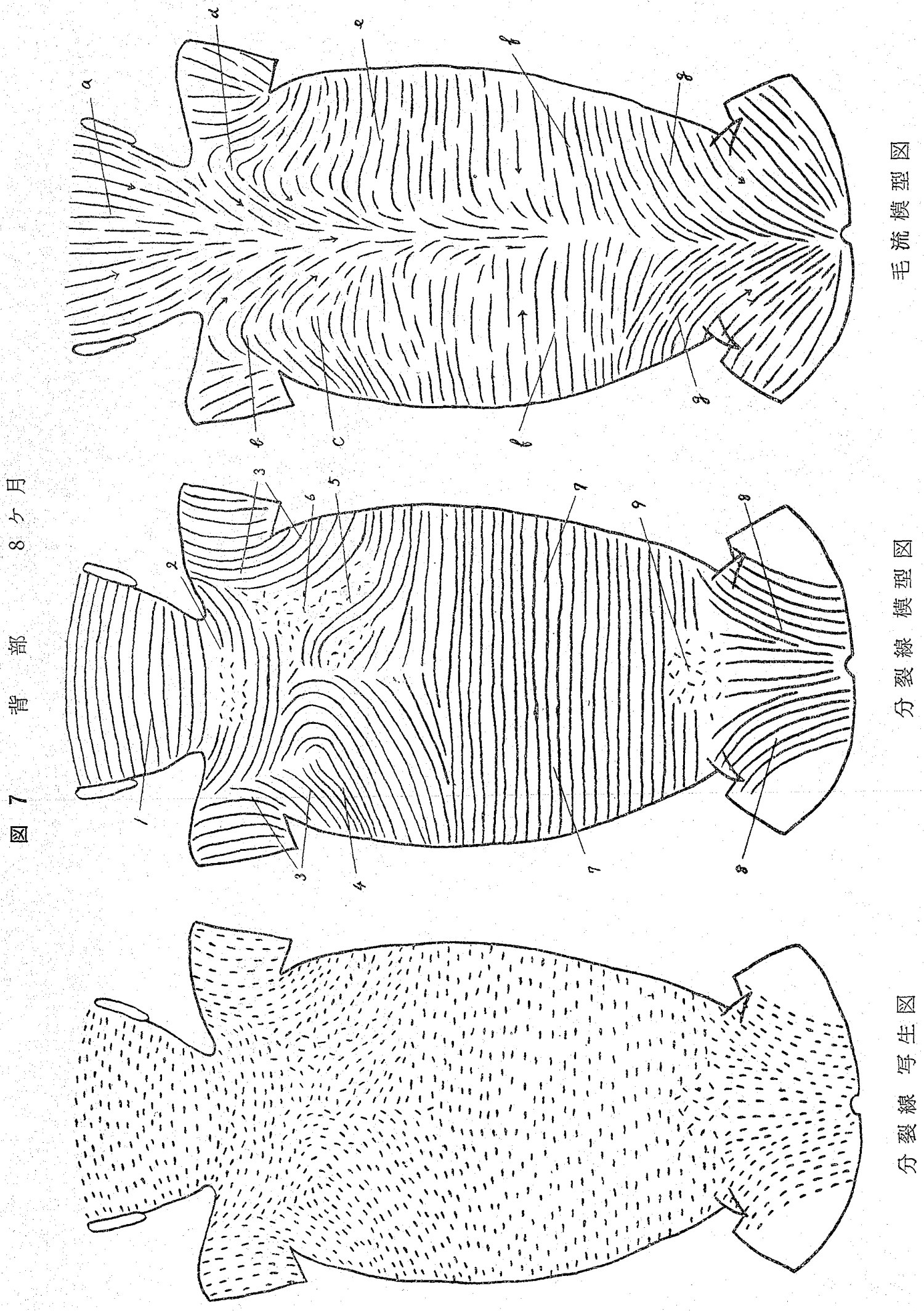

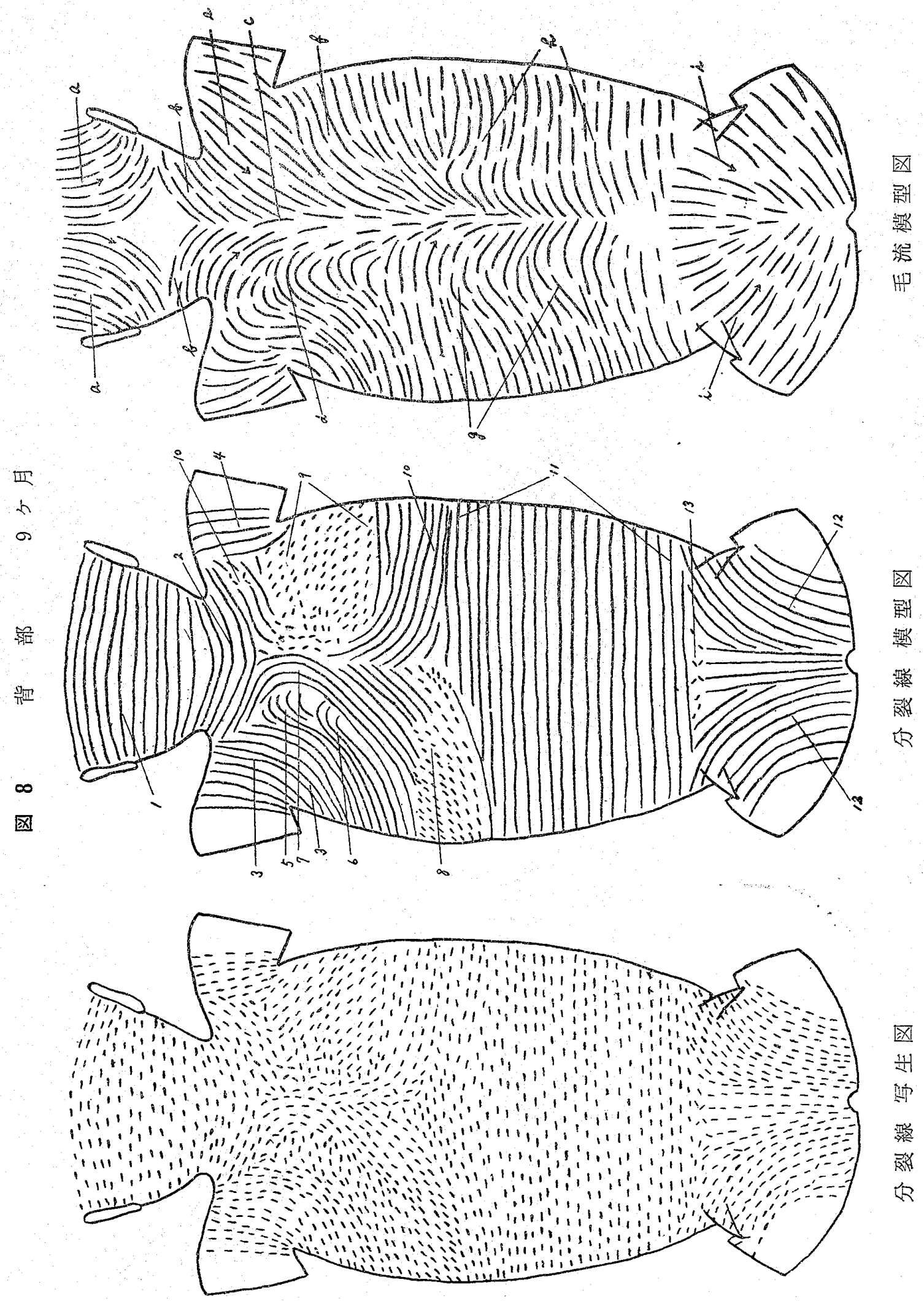

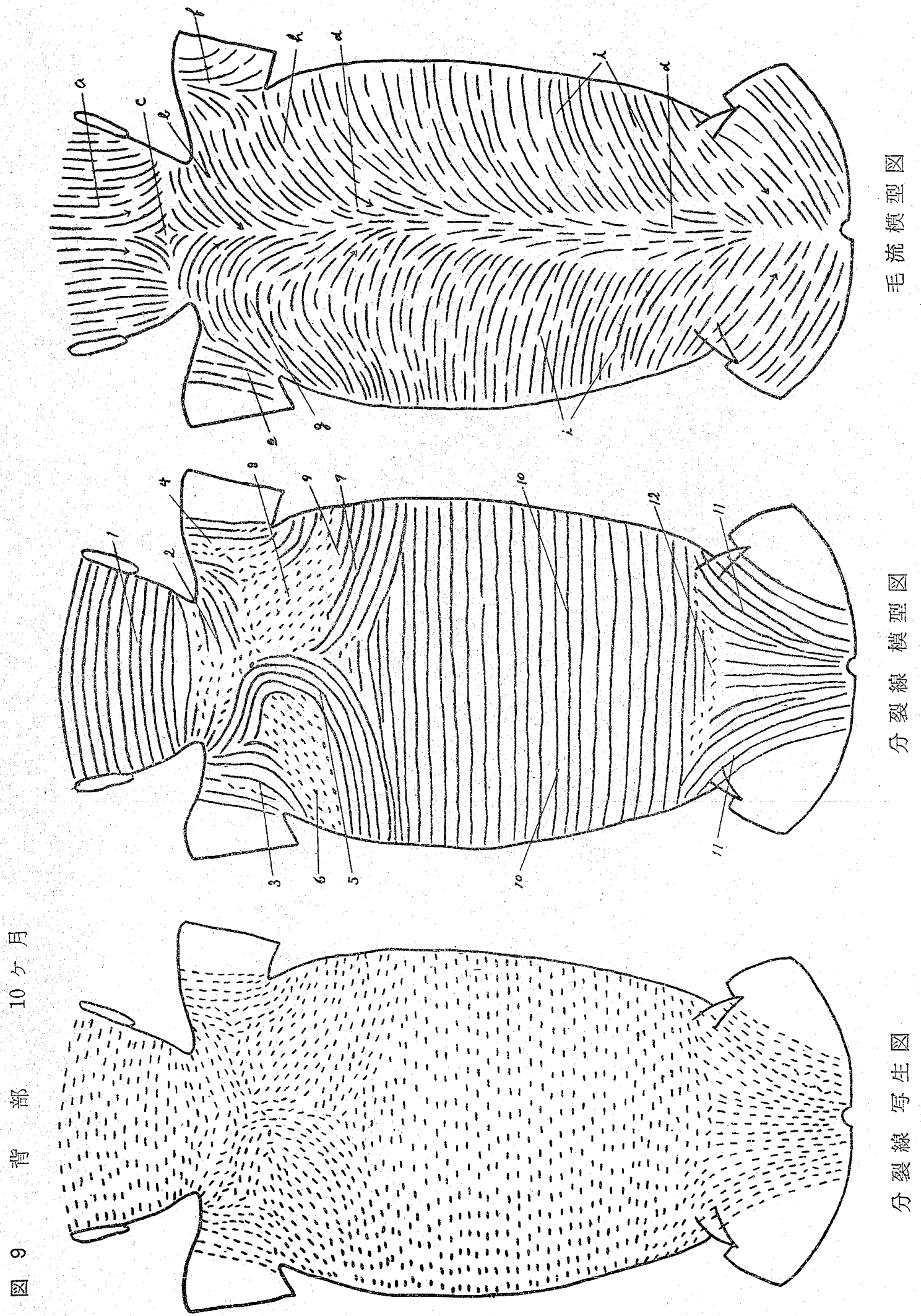


\title{
A STUDY ON THE RELATION BETWEEN THE SPLITTING LINES AND THE HAIR STREAM IN THE SKIN OF HUMAN EMBRYOS
}

\author{
by \\ Tadasu Abe \\ Eepartmeni of Anatomy, Ist Division, Kyushu \\ Dental College (Direcior Prof. Taneaki Nakayama)
}

\begin{abstract}
A comparative observation has been conducted on the behavior of the splitting lines and the hair streams which occurred in the skin covering the head and back of the human embryo. Head region was observed on each stage of embryo from 5 to 8 months of age, and back region on each stage of embryo from 6 to 10 months of age, and thus chronological observation has been made possible to know the possible interaction occurring between the splitting lines and the hair streams in the course fetal life.
\end{abstract}

The results obtained were summarized as follows.

1) In the following regions of the body the two anatomical traits showed similar patterns of orientation through every stages of embryonic life; upper two third of the frontal, upper half of the orbital, the temporal, the parietal, and the occipital regions down to the line connecting the upper roots of right and left auricles; lower lip and chin regions, upper half of mouth region, dorsal sides of the abdomen and the sacral region.

2) The regions where the splitting lines and the hair streams took different directions at early stages of life, but later shared the same direction due to bodily growth were as follows; lower half of the orbital region, periphery of the auricle, cheek region and upper part of the scapular region.

3) There are regions where the splitting lines and the hair streams took the same direction only at certain periods of the fetal life. The regions and the months involved are as follows; at 6 months the whirl of hair part of the parietal region, the vertebral region and its whirl of hair part; at 6 and 8 months those parts extending from the scapular region toward its middle and lower regions.

4) The region where the splitting lines and the hair streams took different directions through entire stages of embryonic life is confined to the part which is bordered upward by the line connecting the upper roots of right and left auricles and downward by the back neck region.

5) A characteristic relation was observed to exist between the splitting lines and the hair streams in the skin in that the normal splitting lines were converted into irregular ones at the following parts of the skin; the part where the hair stream disperses from the middle of the parietal region toward the periphery, the part where crossing of the hair streams takes place in the frontal region, and the part where the fan-like hair stream in the 
sacral region joins with the transversal hair stream of the vertebral region.

6) From histological point of view, the splitting lines of the skin discloses the splitting direction of relatively upper layer of the corium, whereas the direction taken by the hair streams is determined according to the slanting angles of the hair root. It was observed that the age change

in the direction of the hair stream was determined by the direction or the growth orientation of the connective tissue fibers constituting the deeper layer of corium or the superficial layer of subcutaneous tissues in which the hair bulbs were rooted. This probably enplains why the splitting lines and the hair streams alternate their respective courses during the process of embryonic growth.

As is outlined above. the splitting lines and the hair streams in the skin of human embryos undergo changes with age alternately, taking directions at one time similar, at another dissimilar to each other according to stages of the embryonic development.

Thus the fact that the hari streams undergo changes with embrionic growth in close association with the splitting lines suggests that it also would display growth orientation of the skin, or more particularly, the growth orientation of the connective tissue constit uting the deeper layer of corium or the superficial layer of subcutaneous tissue in the skin. It may be also said that the hair streams have close relation with the functional manifestation of the splitting lines in the skin in view of the confirmed specific relation existing between the irregular splitting lines and the hair streams. 